\title{
Clinical and Physiological Consequences of Rapid Tryptophan Depletion
}

Polly Moore, Ph.D., Hans-Peter Landolt, Ph.D., Erich Seifritz, M.D., Camellia Clark, M.D., Tahir Bhatti, M.D., John Kelsoe, M.D., Mark Rapaport, M.D., and J. Christian Gillin, M.D.

We review here the rapid tryptophan depletion (RTD) methodology and its controversial association with depressive relapse. RTD has been used over the past decade to deplete serotonin (5-hydroxy-tryptamine, or 5-HT) in humans and to probe the role of the central serotonin system in a variety of psychiatric conditions. Its current popularity was stimulated by reports that $R T D$ reversed the antidepressant effects of selective serotonin reuptake inhibitors (SSRIs) and monoamine oxidase inhibitors (MAOIs) in remitted patients with a history of depression but not in patients treated with antidepressants which promote catecholaminergic rather than serotonergic neurotransmission (such as tricyclic antidepressants or buproprion). However, RTD has inconsistent effects in terms of full clinical relapse in depressed patients. Pooling the data from all published reports, patients who are either unmedicated and/or fully remitted are much less likely to experience relapse ( 7 of 61 , or $\sim 9 \%$ ) than patients who are recently medicated and partially remitted (63 of 133, or $\sim 47 \%$; although, the numbers here may reflect patient overlap between reports). Recently remitted patients who have been treated with non-pharmacological therapies such as total sleep deprivation, electroconvulsive therapy, or bright light therapy also do not commonly show full clinical relapse with $R T D$. We briefly review $R T D$ effects in other psychiatric disorders, many of which are treated with SSRIs. There is accumulating evidence to suggest that RTD affects central serotonergic neurotransmission. Nevertheless, many questions remain about the ability of RTD to reverse the beneficial effects of SSRIs or MAOIs, or to induce symptoms in unmedicated symptomatic or asymptomatic patients. [Neuropsychopharmacology 23:601-622, 2000] (C) 2000 American College of Neuropsychopharmacology. Published by Elsevier Science Inc.
KEY WORDS: 5-HT; Serotonin; Tryptophan-free drink; Major depression

Serotonin (5-hydroxy-tryptamine, or 5-HT) is involved in many physiologic and behavioral systems and clini-

From the National Multi-Site Training Program on Basic Sleep Research, UCLA Neuroscience Interdepartmental Graduate Program, University of California at Los Angeles, Brain Research Institute, Los Angeles, CA (PM); Department of Psychiatry, University of California at San Diego, UCSD Mental Health Clinical Research Center, VA San Diego Healthcare System, San Diego, CA (PM, H-PL, ES, CC, TB, JK, MR, JCG); Cancer Center, University of California at San Diego, San Diego, CA (PM); and Department of Psychiatry, University of Basel, Basel, Switzerland (ES).

Address correspondence to: J Christian Gillin, M.D., Department of Psychiatry, UCSD, VA San Diego Healthcare System (116A), 3350 La Jolla Village Drive, San Diego, CA 92161.

Received 3 February 2000; revised 18 May 2000; accepted 14 June 2000. cal disease states. Much of the information available on the function of serotonin comes from pharmacological agents which mimic or amplify endogenous serotonergic neurotransmission, such as serotonin agonists or SSRIs. Historically, methods to functionally deplete serotonin have been problematic. Even previous approaches that have been moderately successful in experimental animals - such as the 5-HT synthesis inhibitor, parachloro-phenylalanine (PCPA); the neurotoxin 5-6-dihydroxy-tryptamine; or various lesions to the serotonergic raphe nuclei of the brainstem - have been non-specific, rife with secondary effects, or clearly inapplicable to humans (e.g., Engelman et al. 1967; Koella et al. 1968; Jouvet et al. 1967). The advent of rapid tryptophan depletion (RTD) as a method to deplete central serotonin has been met with enthusiasm because of its reversibil- 
ity, its relative lack of side effects, and its merit in elucidating the pathophysiology of various psychiatric conditions. This paper reviews the RTD methodology and its reported ability to induce a depressive relapse in euthymic patients, and other physiological and clinical effects.

\section{RAPID TRYPTOPHAN DEPLETION}

\section{Availability of Tryptophan and Serotonin Synthesis}

RTD is based on the current understanding of the 5-HT biosynthetic pathway, in which the first step is generally considered to be the rate-limiting one. The first step entails the hydroxylation of the amino acid TRP (by the enzyme TRP hydroxylase, or TRP-H) into the intermediate product 5-hydroxy-tryptophan, or 5-HTP. 5-HTP is then decarboxylated into 5-HT. Under normal conditions, TRP-H is about $50 \%$ saturated with TRP. Increasing or decreasing the availability of TRP correlates highly with the amount of 5-HT produced (e.g., Lin et al. 1969; Schaechter and Wurtman 1990). Because the body cannot synthesize TRP, reducing dietary intake of TRP reduces TRP levels in plasma and diminishes its transport from plasma into the brain.

In humans, TRP depletion is accomplished by consuming a TRP-free amino acid drink (e.g., Delgado et al. 1990; Biggio et al. 1974). This drink contains 15 amino acids in the same proportion as in human milk, except that TRP, aspartic acid, and glutamic acid are omitted (see Table 1). Within a matter of hours (4 to 12), plasma TRP declines to $10-50 \%$ of baseline levels (Delgado et al. 1990, 1991). Similar preparations deplete brain serotonin in animals (e.g., Gessa et al. 1974; Young et al. 1989; Biggio et al. 1974; Moja et al. 1991). The TRP-

Table 1. Composition of the $100 \mathrm{~g}$ Amino Acid Drink Typically Used in RTD Studies, and Aspects of its Amino Acid Contents

\begin{tabular}{lcccc}
\hline Amino Acid & Amount, & Essential & LNAA & Hydrophobic \\
\hline L-alanine & 5.5 & & & $\mathrm{X}$ \\
L-arginine & 4.9 & $\mathrm{X}$ & & \\
L-cysteine & 2.7 & & & \\
Glycine & 3.2 & & & \\
L-histidine & 3.2 & $\mathrm{X}$ & & \\
L-isoleucine & 8.0 & $\mathrm{X}$ & $\mathrm{X}$ & $\mathrm{X}$ \\
L-leucine & 13.5 & $\mathrm{X}$ & $\mathrm{X}$ & $\mathrm{X}$ \\
L-lysine & 11.0 & $\mathrm{X}$ & & \\
L-methionine & 3.0 & $\mathrm{X}$ & & $\mathrm{X}$ \\
L-phenylalanine & 5.7 & $\mathrm{X}$ & $\mathrm{X}$ & $\mathrm{X}$ \\
L-proline & 12.2 & & & \\
L-serine & 6.9 & & & \\
L-threonine & 6.9 & $\mathrm{X}$ & & \\
(L-tryptophan) & $(2.3)$ & $\mathrm{X}$ & $\mathrm{X}$ & $\mathrm{X}$ \\
L-tyrosine & 6.9 & & $\mathrm{X}$ & $\mathrm{X}$ \\
L-valine & 6.9 & $\mathrm{X}$ & $\mathrm{X}$ & $\mathrm{X}$ \\
\hline
\end{tabular}

Abbreviation: LNAA = Large neutral amino acid. depleting effects are enhanced with a low-TRP diet during the day preceding the challenge. To conduct studies according to double-blind, counterbalanced crossover design, subjects ingest either a TRP-free amino acid mixture or a "sham depletion" mixture (identical except that it contains $2.3 \mathrm{~g}$ TRP).

\section{Tryptophan in Plasma, and Entry into Brain}

Free versus bound TRP. Total TRP in plasma is comprised of free TRP plus (albumin-) bound TRP (McMenamy 1965). Only free TRP crosses the blood brain barrier (BBB), thus brain TRP levels are more accurately predicted by free TRP than total TRP levels (Tagliamonte et al. 1973). Factors such as plasma levels of non-esterified fatty acids (NEFA), which affect protein binding of TRP, may be relevant to RTD. NEFA displace TRP from its binding site on albumin (Curzon 1979), thus, potentially affecting the assignment of TRP to free vs. bound.

Other Amino Acids. Plasma levels of other amino acids are also important. TRP crosses over from plasma into the CNS via a specific BBB carrier (Oldendorf and Szabo 1976). All large neutral amino acids (LNAAs: $\mathrm{TRP}$, phenylalanine, leucine, isoleucine, tyrosine, and valine) (see Table 1) are transported by the same carrier, and thus compete with TRP for brain entry at these sites. Therefore, the TRP:LNAAs ratio more accurately predicts brain TRP levels than absolute plasma TRP (e.g., Perez-Cruet et al. 1974; Fernstrom and Wurtman 1974; Fernstrom 1979).

Circadian and Dietary Influences. Plasma TRP levels exhibit diurnal or circadian variation in many species. In healthy human males after an overnight fast, plasma TRP reaches its minimum in the morning and peaks in the late evening (Wurtman et al. 1968). However, circadian influences are relatively minor compared to the influence of dietary intake. Foods that elevate brain TRP result in increased 5-HT synthesis (Fernstrom et al. 1979; Wurtman and Pardridge 1979). Paradoxically, this is accomplished by foods high in carbohydrate content, rather than high in protein and TRP. High-protein foods are rich in other amino acids that compete with TRP at the BBB, reducing TRP entry into brain. In part, high carbohydrate meals increase brain 5-HT by inducing insulin secretion, which traffics amino acids out of plasma and into tissue, leading to less competition for TRP uptake into CNS (Fernstrom et al. 1979).

Like a high protein meal, RTD introduces into plasma a bulk of amino acids that compete with TRP at the BBB. The amino acid load also stimulates protein synthesis, taking free TRP out of plasma and into new proteins (Moja et al. 1991).

Slowly depleting tryptophan by administration of long-term low-TRP diets to rats or humans (Moja et al. 1979; Lanoir et al. 1981; Delgado et al. 1989) reduces 
plasma TRP below pre-diet baseline levels, although these reductions are relatively modest (e.g., to levels approximately $80 \%$ of baseline) compared with the effects of rapid tryptophan depletion (plasma TRP declines to $10-50 \%$ of baseline). Behavioral effects may be minimal or not sustained for the duration of the diet, possibly due to CNS adaptations.

\section{RTD and 5-HT Release from Neurons}

Early studies in rats showed that whole-brain 5-HT levels generally declined with RTD preparations of various kinds, but non-neuronal sources of 5-HT may have contaminated these findings. It is also unknown whether vesicular or cytoplasmic stores of neuronal 5-HT were preferentially affected. Since the firing rate of serotonergic raphe neurons appears to be unaffected by changes in TRP intake (Trulson 1985), it is important to establish RTD's effect on neuronal release, and attempts to do so have been promising.

In vivo microdialysis measurements at projection sites of raphe neurons indicate changes in vesicular (i.e., action potential and $\mathrm{Ca}++$-dependent) 5 -HT release. Systemic administration of 5-HT synthesis precursors such as L-TRP (Sharp et al. 1992) or 5-hydroxy-tryptophan (Gartside et al. 1992c) produced long-lasting and dose-dependent increases in 5-HT release in the ventral hippocampus and ventral hypothalamus, respectively. Decreases in electrically evoked 5-HT release in rat hippocampus followed systemic administration of valine, an LNAA (Gartside et al. 1992b). As an aside: in depressed patients and healthy subjects, administration of $30 \mathrm{~g}$ valine produced modest changes in mood, although not depressive relapse, compared to placebo (see Cowen et al. 1996). Administering an amino acid mixture also leads to decreased 5-HT release in rats, compared to saline vehicle (Gartside et al. 1992a), by about $45 \%$ of baseline.

In rats, an RTD-like mixture diminished 5-HT release measured by microdialysis in frontal cortex to about $50 \%$ of baseline, in a time course similar to the behavioral effects seen in analogous human studies (Bel and Artigas 1996). Other approaches have reported declines in hippocampal and striatal 5-HT with RTD-like preparations (Brown et al. 1998). It should be noted that 5-HT microdialysis studies are often performed under general anesthesia, in a state that is different from wakefulness or sleep, and state of consciousness is the single most prominent influence on the firing activity of the raphe (Jacobs et al. 1990; Fornal et al. 1994). Furthermore, substances such as SSRIs or fenfluramine are often added to the preparation in order to enhance 5-HT release to measurable levels. With current technology, levels of 5-HT release under baseline conditions are too low to be detected. At this point, it is difficult to ascertain changes in 5-HT levels in a state uninfluenced by 5-HT enhancing drugs.

\section{RTD and the Neuroanatomy of the Serotonergic Raphe of the Brainstem}

Due to its neuroanatomy and role in neurodevelopment, 5-HT is well positioned to modify most other neurotransmitter systems in the CNS. The cell bodies of the serotonin-producing raphe neurons are clustered along the midline of the brainstem and midbrain (fairly early-evolved brain structures). The projections of these neurons and hence the sites of potential 5-HT influence extend over every level of the neuraxis. These other systems could be affected or disrupted by a sudden drop in 5-HT release. In this way, the RTD paradigm might simply uncover other systems normally being modulated, modified, or otherwise regulated by 5-HT. For example, in neocortex as well as within hippocampal structures, serotonin receptors are found on other interneurons (Tork 1990). 5-HT by itself does not alter firing of quiescent spinal motor cord neurons, but it is believed to alter the response threshold to glutamate (Baumgarten and Grozdanovic 1995). Serotonergic projections are also known to facilitate the dopaminergic mesolimbic reward pathway, to inhibit the noradrenergic locus ceruleus system, and to inhibit release of acetylcholine in hippocampus and cortex (Baumgarten and Grozdanovic 1994).

\section{Evidence that RTD Reduces 5-HT in Human Volunteers or in Animals}

Plasma TRP. Over dozens of studies, the RTD paradigm produces a consistent and robust attenuation of TRP levels in plasma (see Tables 2, 3, and 4).. Even when the specific composition of amino acid challenge itself is altered, plasma TRP falls. Lesser degrees of plasma TRP depletion are observed when smaller total amounts of amino acids are ingested (Moja et al. 1988, 1989). Larger amounts of amino acids not only produce lower nadirs of TRP in plasma, but also prolong the time to nadir (Moja et al. 1989).

\section{Melatonin Secretion, CSF Levels of TRP and CSF Levels of Serotonin Metabolite, 5-Hydroxy-Indole Acetic Acid} (5-HIAA). Serotonin is an intermediary product in melatonin synthesis. Compared to sham depletion, RTD significantly attenuated the secretion of melatonin across the night in eight of eight healthy volunteers (Zimmerman et al. 1993) (see Table 2). Levels of TRP in cerebrospinal fluid (CSF) and CSF levels of 5-HT metabolite 5-HIAA were significantly diminished within two hours of RTD ingestion and reached their nadir around six to twelve hours post-ingestion (Williams et al. 1999; Carpenter et al. 1998).

5-HT Synthesis Measured by Positron Emission Tomography (PET). Nishizawa et al. (1997) devised a PET method to estimate rates of serotonin synthesis, in 
Table 2. Evidence that Different Preparations of RTD Deplete Central Serotonin, in Healthy Human Volunteers or in Animals

\begin{tabular}{|c|c|c|c|c|}
\hline Measure of Interest & Reference & Subjects & $\begin{array}{l}\text { \% TRP } \\
\text { Decline }\end{array}$ & Results and Comments \\
\hline $\begin{array}{l}\text { Plasma TRP, brain TRP, } \\
\text { and brain 5-HT }\end{array}$ & Moja et al. 1988 & 28 male Wistar rats & (see results) & $\begin{array}{l}\text { Rats were administered water or one of three } \\
\text { mixtures of amino acids in differing strengths. } \\
\text { The decrease in total plasma TRP, free brain } \\
\text { TRP, brain 5-HT and brain 5-HIAA was } \\
\text { proportional to the amount of amino acids } \\
\text { ingested. }\end{array}$ \\
\hline Brain 5-HT & Biggio et al. 1974 & Male Wistar rats & $\sim 10 \%$ & $\begin{array}{l}\text { Rats ingested either a } 10.5 \mathrm{~g} \text { tryptophan- } \\
\text { containing diet or a } 10.3 \mathrm{~g} \text { tryptophan-free diet. } \\
\text { Both diets also contained other nutrients in } \\
\text { addition to amino acids. Brain 5-HT declined to } \\
43 \% \text { of baseline values, an effect that was } \\
\text { maximal within two hours of ingestion. }\end{array}$ \\
\hline $\begin{array}{l}\text { 5-HT release from } \\
\text { neurons }\end{array}$ & $\begin{array}{l}\text { Gartside et al. } \\
\text { 1992a and b }\end{array}$ & $\begin{array}{l}\text { Male Sprague- } \\
\text { Dawley rats }\end{array}$ & n.r. & $\begin{array}{l}\text { Rats were administered either vehicle, L-valine, } \\
\text { or a mixture of amino acids. L-valine or amino } \\
\text { acids (but not vehicle) led to decreases in 5-HT } \\
\text { release from serotonergic raphe neurons at } \\
\text { hippocampal projection sites. Measurements } \\
\text { were taken in anesthetized rats. }\end{array}$ \\
\hline $\begin{array}{l}\text { 5-HT release from } \\
\text { neurons }\end{array}$ & $\begin{array}{l}\text { Bel and Artigas. } \\
1996\end{array}$ & Male Wistar rats & n.r. & $\begin{array}{l}\text { Amino acid mixtures comparable to those used in } \\
\text { human RTD studies were administered to rats. } \\
\text { The tryptophan-free amino acid mixture led to } \\
\text { reduced 5-HT release from serotonergic raphe } \\
\text { neurons in frontal cortex, but only in animals } \\
\text { that had been pre-treated for two weeks with } \\
\text { SSRI. }\end{array}$ \\
\hline $\begin{array}{l}\text { Cerebrospinal fluid } \\
\text { (CSF) levels } \\
\text { of TRP \& 5-HIAA }\end{array}$ & $\begin{array}{l}\text { Williams et al. } \\
1999\end{array}$ & $2 \mathrm{~F}, 4 \mathrm{M}$ & $87 \%$ & $\begin{array}{l}\text { Measured the levels of TRP and 5-HIAA in } \\
\text { cerebrospinal fluid (CSF). In the hours } \\
\text { following RTD, TRP in CSF declined similar to } \\
\text { the TRP decline in plasma. CSF 5-HIAA levels } \\
\text { also dropped compared to baseline, but to a } \\
\text { lesser extent than plasma TRP did. }\end{array}$ \\
\hline $\begin{array}{l}\text { CSF levels of TRP } \\
\quad \& 5 \text {-HIAA }\end{array}$ & $\begin{array}{l}\text { Carpenter et al. } \\
\quad 1998\end{array}$ & $2 \mathrm{~F}, 3 \mathrm{M}$ & $85 \%$ & $\begin{array}{l}\text { Measured CSF levels of TRP and 5-HIAA, as well } \\
\text { as CSF levels of tyrosine and homovanillic acid } \\
\text { (HVA). CSF TRP declined to } 10 \% \text { of baseline; } \\
\text { CSF 5-HIAA declined to } 24-40 \% \text { of baseline. } \\
\text { No effects were found for tyrosine nor HVA, } \\
\text { suggesting specificity RTD's for the 5-HT } \\
\text { system. }\end{array}$ \\
\hline Secretion of melatonin & $\begin{array}{l}\text { Zimmerman et al. } \\
1993\end{array}$ & $4 \mathrm{~F}, 4 \mathrm{M}$ & $90 \%$ & $\begin{array}{l}\text { All } 8 \text { subjects showed decreased melatonin } \\
\text { measurements across the night. Here, the RTD } \\
\text { challenge had been administered at 3pm (in } \\
\text { contrast to } 8 \text { or } 9 \text { am in most studies). }\end{array}$ \\
\hline Neuroendocrine effects & Coccaro et al. 1998 & $6 \mathrm{M}$ & $79 \%$ & $\begin{array}{l}\text { Measured the prolaction response to d- } \\
\text { fenfluramine challenge. Pre-treatment with } \\
\text { RTD attenuated the prolactin response. }\end{array}$ \\
\hline $\begin{array}{l}\text { Serotonin synthesis } \\
\text { [measured by positron } \\
\text { emission tomography } \\
\text { (PET)] }\end{array}$ & $\begin{array}{l}\text { Nishizawa et al. } \\
\quad 1997\end{array}$ & $7 \mathrm{~F}, 8 \mathrm{M}$ & $\begin{array}{r}\text { F: } 88 \% \\
\text { M: } 73 \%\end{array}$ & $\begin{array}{l}\text { Rates of 5-HT synthesis were calculated from PET } \\
\text { measurements before and after RTD. Baseline } \\
\text { pre-RTD synthesis rates were much lower in } \\
\text { females than males. In addition, following } \\
\text { RTD, females' rates of } 5 \text {-HT synthesis were } \\
\text { depleted by a greater fraction compared with } \\
\text { males (females: } 1 / 40^{\text {th }} \text {, males: } 1 / 10^{\text {th }} \text { ). }\end{array}$ \\
\hline EEG sleep & Bhatti et al. 1998 & $10 \mathrm{M}$ & $79 \%$ & $\begin{array}{l}\text { Administered } 25 \mathrm{~g} \text { or } 100 \mathrm{~g} \text { mixture at } 3 \mathrm{pm} .100 \mathrm{~g} \\
\text { elicited a significant reduction of REM sleep } \\
\text { latency in nighttime sleep recordings. } 25 \mathrm{~g} \\
\text { challenge also produced significant changes in } \\
\text { REM sleep, findings consistent with a } \\
\text { reduction in 5-HT release from neurons. }\end{array}$ \\
\hline
\end{tabular}

Abbreviations: TRP = tryptophan; 5-HT = serotonin; 5-HIAA = 5-hydroxy-indole acetic acid; EEG = electroencephalographic.

$\%$ TRP decline indicated the average drop from baseline in free plasma TRP, unless otherwise noted.

healthy males and females, before and after RTD. There were pronounced gender differences in 5-HT synthesis at baseline, prior to challenge, and this difference was compounded by RTD. At baseline, women had lower rates of synthesis at baseline than men (average synthesis rates in men were approximately $50 \%$ greater). Fur- thermore, 5 hours post-RTD, 5-HT synthesis in men was reduced from baseline by a factor of ten by RTD, whereas in women RTD reduced 5-HT synthesis by a factor of forty.

This study indicated drastic reductions in synthesis in virtually all brain regions measured (frontal cortex, 
parietal cortex, temporal cortex, occipital cortex, caudate, putamen, globus pallidus, thalamus, hypothalamus, amygdala, and hippocampus). PET measures of cerebral metabolism (e.g., Bremner et al. 1997, mentioned below) do not reveal anything specific about central 5-HT release, but the idea that RTD has CNS effects is supported by these studies.

Neuroendocrine Effects of RTD. Prolactin responses to $\mathrm{d}$-fenfluramine were attenuated following RTD but not after sham depletion (Coccaro et al. 1998).

Polysomnographic Sleep Measures. A cluster of abnormalities in polysomnographically recorded EEG sleep - such as reduced latency to rapid eye movement (REM) sleep, and increased REM sleep duration, REM sleep percent of total sleep time, and REM density - are often associated with depressive illness (Benca et al. 1992). Administration of SSRI suppresses these REM sleep variables (e.g., Gillin et al. 1997) in depressed and non-depressed subjects.

In SSRI-treated fully remitted depressed men, we found that RTD induced depression-like increases in all REM sleep measures (Moore et al. 1998). In other words, RTD produced "depressed" sleep in remitted patients without clinically significant changes in scores on the Hamilton Depression Rating Scale (HDRS). Monoamine oxidase inhibitors (MAOIs) may suppress REM sleep even more effectively than SSRIs (Wyatt et al. 1969; Landolt et al. 1999). Preliminary data suggest that RTD disinhibits this REM sleep suppression and elicits large increases in REM sleep time without clinically significant depressive relapse in recently remitted phenelzine-treated depressed patients. For example, in one patient, REM time increased from zero minutes on phenelzine to 140 minutes on phenelzine and RTD, but not on phenelzine and sham challenge (Landolt et al. 2000). Polysomnographic sleep measures were also significantly affected by RTD in one report (Bhatti et al. 1998) but not in another (Voderholzer et al. 1998). Bhatti et al. (1998) reported that two strengths of RTD (100 and $25 \%$ ) dose-dependently reduced REM latency compared to a baseline sleep night, and the $25 \%$ RTD significantly increased REM percentage. The RTD-induced disinhibition of REM sleep would be consistent with considerable data regarding serotonergic inhibitory control of REM sleep. In particular, it is consistent with animal data in which the withdrawal of 5-HT release quickly leads to onset of REM sleep (Portas and McCarley 1994; Portas et al 1996).

\section{RTD and Depressive Relapse: Does RTD Reverse the Beneficial Effect Treatment Preferentially with Different Types of Antidepressants?}

Partial Remission, Antidepressant Treatment. The popularity of RTD resulted from several early studies in which the antidepressant effects of SSRIs or MAOIs were temporarily reversed (Delgado et al. 1990, 1991, 1994). RTD, but not the TRP-containing sham challenge, induced a depressive relapse in 14 of 21 inpatients hospitalized for major depressive disorder who had responded well to antidepressant therapy (defined as a $50 \%$ improvement in HDRS, and symptomatic stability for two weeks) (Delgado et al. 1990) (see Table 3).

A "depressive relapse" was defined as an increase in pre-challenge HDRS score by at least $50 \%$ or a score $>17$. Mood gradually returned to pre-RTD levels with resumption of a normal diet. Case reports suggested that the individual's symptom profile prior to treatment seemed to re-emerge following RTD. These findings with RTD are consistent with those using an earlier method of depleting serotonin, PCPA. In those studies, PCPA elicited depressive relapse in a similar fashion in MAOItreated recently remitted patients (Shopsin et al. 1976). Its use was discontinued because of adverse side effects.

It bears mentioning that "depressive relapse" has been defined differently. Here, for the purpose of comparison, a single set of relapse criteria was employed. The relapse criteria defined by Delgado et al. (1990) is the most restrictive: an increase in pre-challenge HDRS score by at least $50 \%$ and $>17$. Lesser changes in depressive symptoms as measured by HDRS are meaningful, but the relationship to full clinical relapse is unclear.

In patients treated with antidepressants such as MAOIs or SSRIs that primarily enhance 5-HTergic neurotransmission, RTD led to an $80 \%$ rate of relapse (16 of 22 patients) (Delgado et al. 1991). Only 18\% (two of 13) of desipramine- or buproprion-treated (reuptake inhibitors of norepinephrine or dopamine, respectively) patients relapsed with RTD (Delgado et al. 1991, 1993, 1994). A subsequent study directly compared RTD responses in patients recently treated with fluoxetine vs. desipramine. Relapse occurred in eight of 15 fluoxetinetreated patients, compared with only one of 15 on desipramine (Delgado et al. 1999).

Full Remission. Whether drug-free or still on $\mathrm{AD}$ treatment, fully remitted patients who are have been euthymic for at least two months relapse very rarely with RTD. Moreno et al. (1999) compared mood responses to RTD in twelve fully remitted drug-free patients with twelve subjects with no history of depression. Only the patients experienced depressive changes measured by HDRS. Again, full clinical relapse was rare, and mood alterations in general were highly variable in magnitude and time course. In a study by Smith et al. (1997), five of 15 euthymic women with a history of depression were reported to relapse, but possibly only two of these met criteria for full clinical relapse (as defined by Delgado et al. (1990)). Even lower relapse rates were found in other studies; Leyton et al. (1997) found no mood changes following RTD in 14 drug-free 


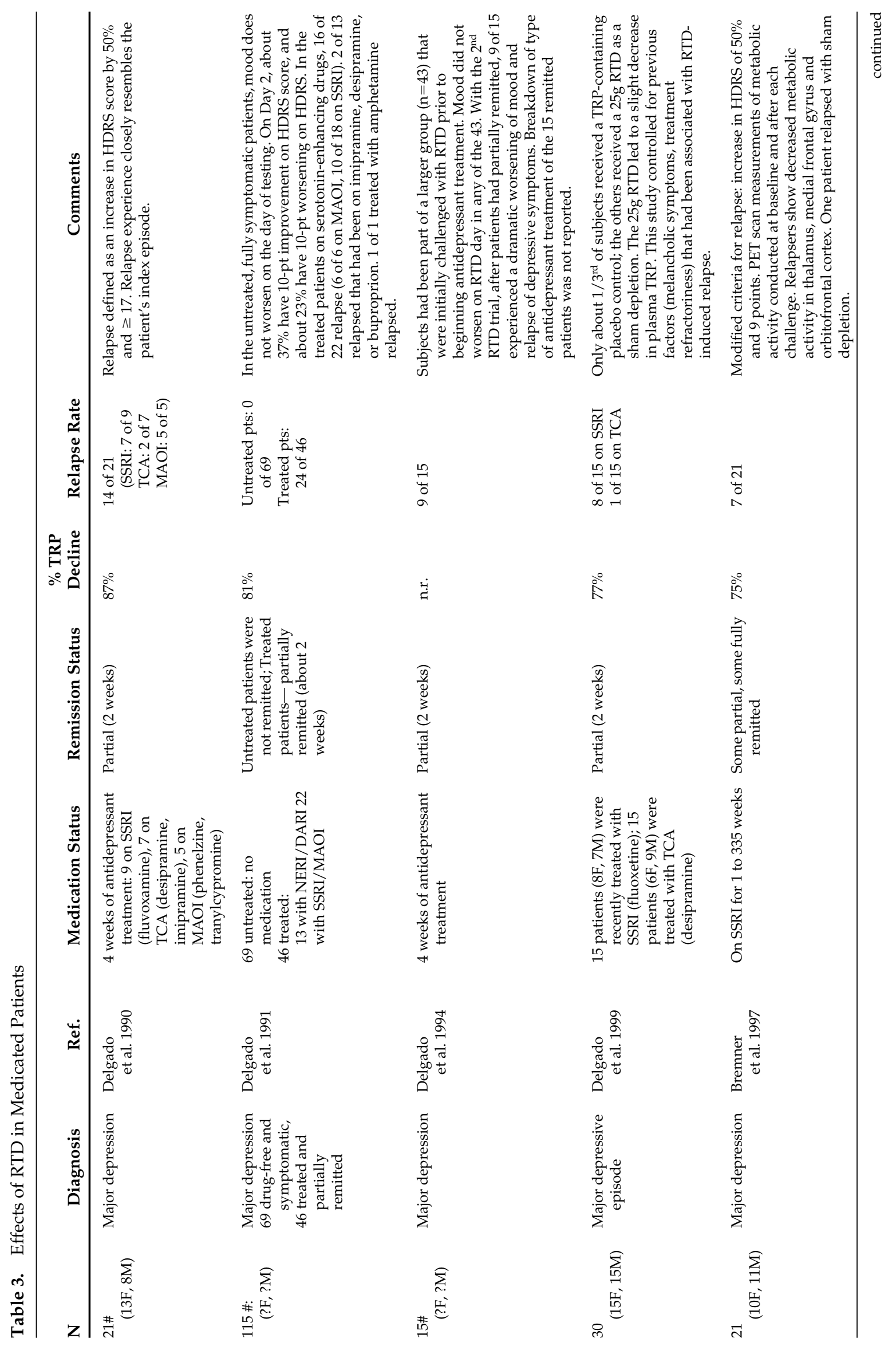




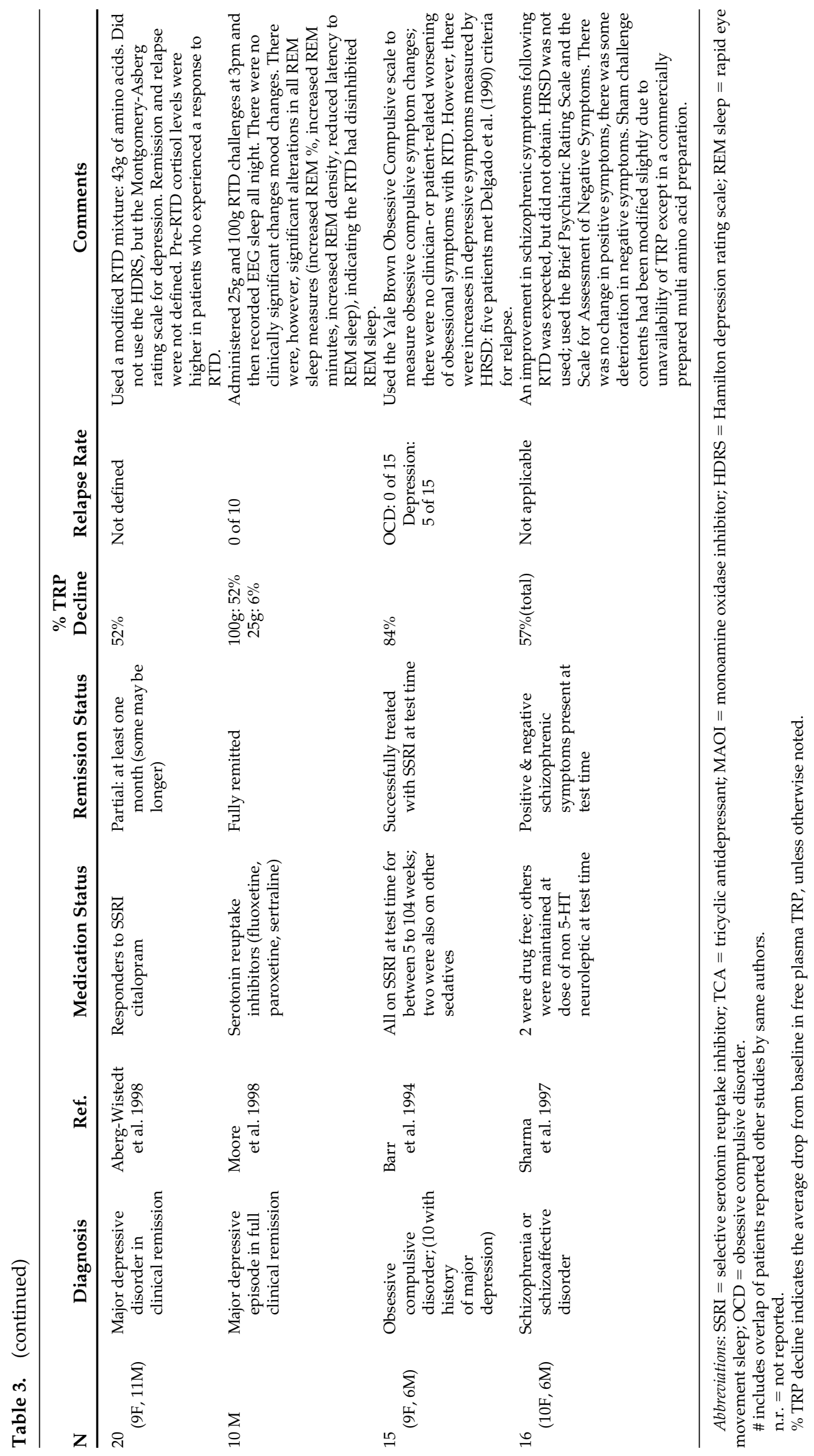


recovered patients, and Moore et al. (1998) found no relapse in 10 fully-remitted SSRI-treated patients, even though RTD significantly lowered plasma TRP concentrations and induced depression-like sleep alterations (shortened REM latency, and increased REM percent and REM density).

With the exception of Bremner et al. (1997), whose subjects had been on SSRIs for two to 337 weeks and most likely included some recently remitted patients, there has been little additional data in recently remitted pharmacologically treated patients.

Momentary 5-HT availability may be critical for maintaining mood only during certain critical time periods in antidepressant-induced recovery (Blier and de Montigny 1994; Artigas et al. 1996), but not at other time points. We speculate that this temporary dependence on 5-HT in early stages of remission may account for some of the variability in mood effects of RTD.

The current evidence suggests that the RTD-induced relapse of depressive symptoms is more likely earlier in remission rather than later, and when treated with SSRIs or MAOIs compared with catecholamine-enhancing drugs.

Obsessive-Compulsive Disorder and Panic Disorder, Symptomatic and Untreated. Obsessive-compulsive symptoms in SSRI-treated or drug-free obsessive compulsive disorder patients did not worsen following RTD, in either subjective or clinician rated assessment scales (Barr et al. 1994) (see also Table 4 in unmedicated patients) (Smeraldi et al. 1996). Depressive relapse was seen in five of 15 patients with obsessive compulsive disorder, some of whom also had some depressive symptoms prior to RTD challenge (Barr et al. 1994).

\section{Other Psychiatric Diagnoses}

Late Luteal Phase Dysphoric Disorder (LLPDD), or Premenstrual Syndrome. Female patients with monthly depression, or late luteal phase dysphoric disorder (LLPDD), did not experience changes in HDRS after RTD (Menkes et al. 1994); however, RTD did elicit significant increases in subjectively-rated LLPDDrelated symptoms compared with sham depletion. Each of these patients underwent two challenges during each of two phases of the menstrual cycle, the follicular phase and the luteal phase. During the follicular phase, RTD induced an LLPDD-like state in a subgroup of the women, and during the luteal phase, RTD significantly worsened ratings of irritability. A group of normal comparison subjects would have helped to illuminate whether women in general are more vulnerable to mood effects with RTD during different phases, and this topic will be returned to below. Menstrual physiology may significantly impact RTD results in only a subgroup of women, yet until these factors are better un- derstood, it is probably prudent to control for cycle phase.

Autism. Eleven of 17 autistic adults showed a significant worsening of symptoms following RTD with both clinically based and subjectively rated symptom assessments (McDougle et al. 1996). RTD but not sham depletion led to increases in autistic behaviors (such as whirling, flapping, pacing, banging and hitting self, rocking and toe walking, etc.) and alterations in emotional states.

Cocaine Craving and Reward. In cocaine addicts, RTD affected the subjective craving for cocaine as well as its rewarding qualities. When patients were exposed to cocaine-related paraphernalia (specifically intended to enhance craving), RTD diminished the subjective feelings of craving (Satel et al. 1995). In another group of addicts, RTD diminished the "high" feeling after intranasal cocaine when compared with sham challenge (Aronson et al. 1995). Since serotonergic raphe neurons are known to modulate mesolimbic dopaminergic reward pathways believed to mediate the rewarding properties of all known drugs of abuse (Baumgarten and Grozdanovic 1994), these findings imply that RTD directly reduces the pleasurable subjective states related to drug craving and drug reward.

Bulimia. In bulimic women, whether recently symptomatic or abstinent for six months, RTD has inconsistent mood lowering effects (Weltzin et al. 1994, 1995; Oldman et al. 1995). However, RTD-induced effects on food choices in a test meal following RTD, as well as increased irritability, and changes in eating cognitions and self-perceptions have been observed. By contrast, changes in healthy volunteers' food choices have been subtle (Young et al. 1988; Oldman et al. 1994). Smith et al. (1999) found that drug-free women with a history of bulimia and major depression had a modest lowering of mood (mean change in HDRS $\sim 8$ points), and increases in body-image and eating-control related fears and cognitions. Normal comparison subjects did not show these changes.

Tourette's Syndrome. Unmedicated Tourette's syndrome patients did not show worsening of clinicianrated tic, obsessive/compulsive, or mood symptoms with RTD (Rasmussen et al. 1997).

Intermittent Explosive Disorder. Other negative findings include clinician-rated aggressive behavior in patients hospitalized with intermittent explosive disorder (Salomon et al. 1994). By comparison, effects of RTD on measures of aggression in healthy subjects are also somewhat mixed. In some but not all studies, significant increases in RTD-increased aggressive responding in experimentally-controlled situations have been re- 


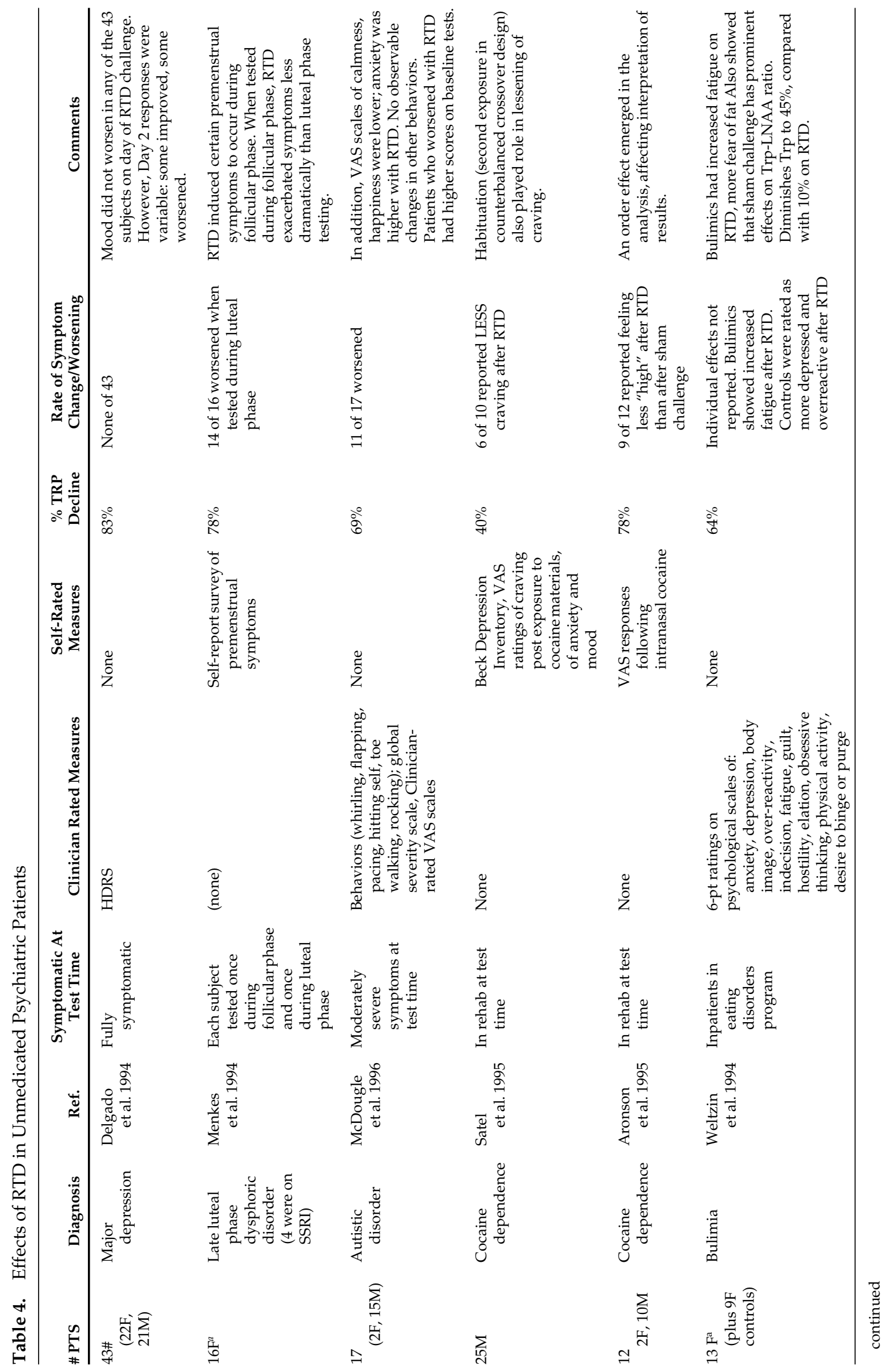




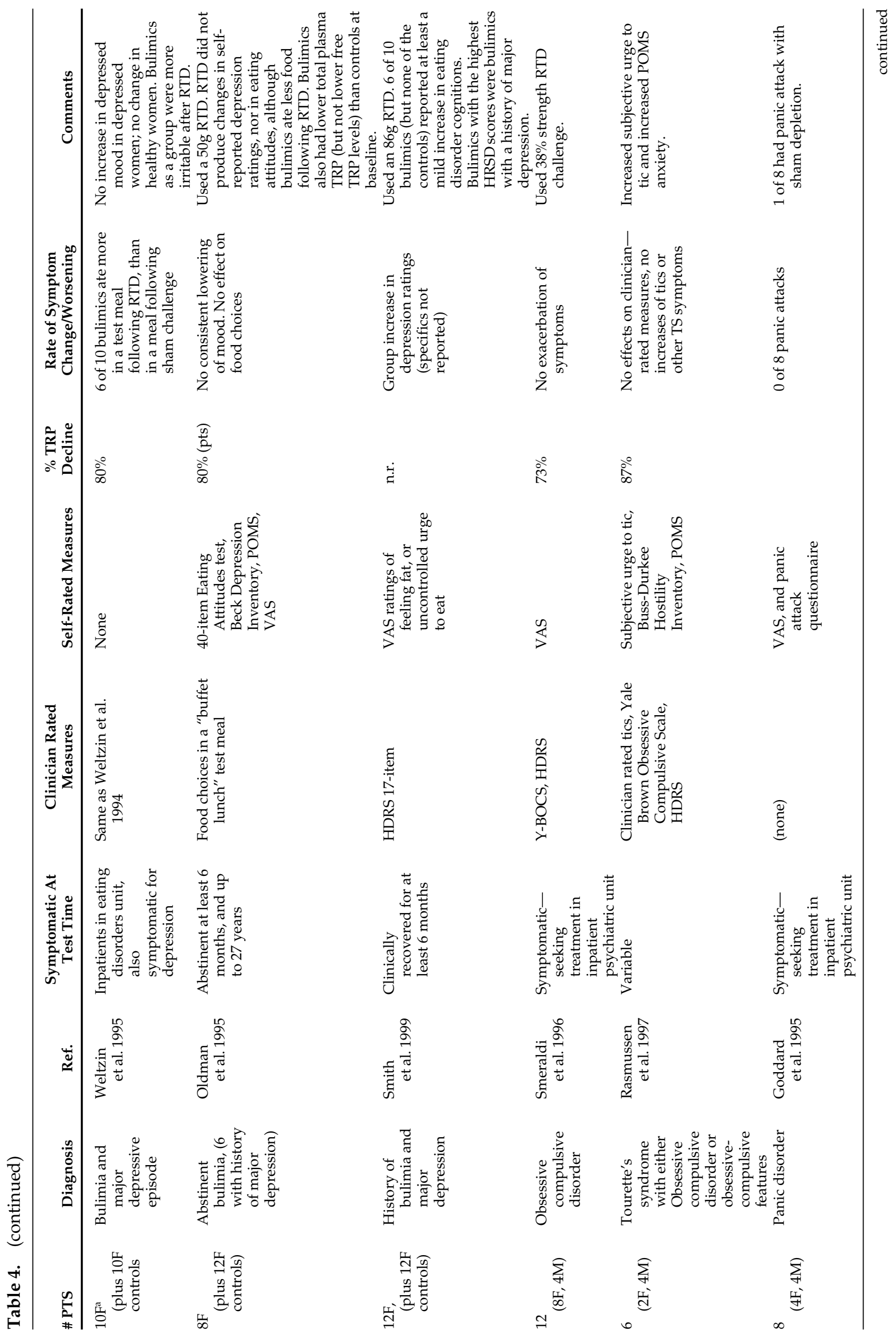




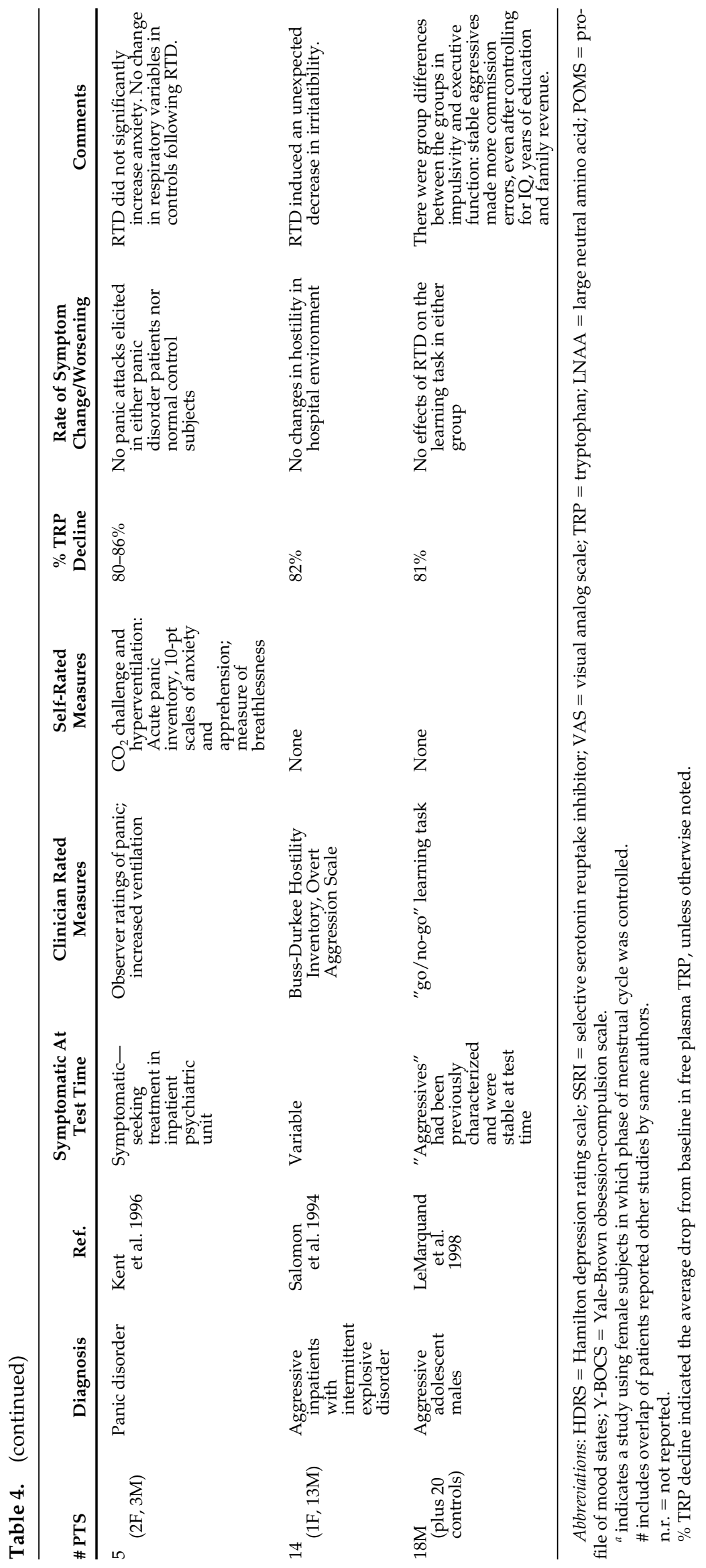


ported (Moeller et al. 1996; Bjork et al. 1999; LeMarquand et al. 1998; Cleare and Bond 1995).

Schizophrenia. Schizophrenic patients with positive and negative symptoms had been expected to improve with RTD, but did not. In fact, negative symptoms worsened slightly, thus not supporting a clear role for serotonin in these clinical symptoms (Sharma et al. 1997).

RTD also failed to develop panic attacks in medication-free, symptomatic panic disorder patients (see Table 4) (Goddard et al. 1995; Kent et al. 1996). These two studies do not necessarily negate serotonergic involvement in panic, anxiety and related symptoms. Other reports indicate significant respiratory responses to RTD in panic disorder patients but not normal comparison subjects (Kent et al. 1996). Increases in anxiety responses to $\mathrm{CO} 2$ challenge were seen in healthy subjects (Goddard et al. 1995; Klaassen et al. 1998). Enhancements in subjects' ratings of nervousness in response to i.v. yohimbine (an $\alpha_{2}$ norepinephrine antagonist that often leads to a worsening of anxiety symptoms) were seen with RTD compared to control testing (Goddard et al. 1995).

\section{What Effect Does RTD Have on Symptomatic Unmedicated Patients?}

In 49 untreated (drug-free) fully symptomatic depressed patients, RTD induced little mood change (Delgado et al. 1993). After treatment with various types of $A D$ (TCA, SSRI, MAOI), 15 of these patients were re-challenged with RTD after four weeks' remission. Nine experienced a depressive relapse upon the repeat-RTD day. Whether type of $\mathrm{AD}$ was associated with relapse here was not reported.

Similar to the RTD approach, the relapse-inducing effects of depleting catecholamines (with $\alpha$-methylpara-tyrosine, AMPT, a blocker of catecholamine synthesis) have also been investigated (Miller et al. 1996; Heninger et al. 1996). AMPT-induced changes mimic those with RTD in terms of effects in recently remitted patients with specific pharmacotherapies. Specifically, AMPT induced relapse in all recently remitted patients on catecholamine-enhancing drugs (five of five on desipramine, a norepinephrine reuptake inhibitor; or mazindol, a dopamine reuptake inhibitor), whereas only one of nine SSRI-treated patients relapsed with AMPT. Similar to RTD, AMPT had no effect on HDRS scores when given to acutely ill drug free depressed patients, despite changes in plasma levels of catecholamine metabolites. Interestingly, though tyrosine is the substrate for catecholamine synthesis, in a pathway analogous to that for TRP and 5-HT, acutely depleting the amino acid tyrosine is not typically the approach used to deplete catecholamines. This is believed to be so because of two critical differences between tyrosine and
TRP. For one, tyrosine availability is not the rate-limiting step in synthesis. Second, tyrosine is not an essential amino acid, since the liver can synthesize it from another amino acid, phenylalanine (Fernstrom and Wurtman 1974) (see Table 1).

\section{RTD and Physiologic Variables Associated with Depression}

PET measures of cerebral glucose metabolism were taken in SSRI-treated euthymic depressed patients following RTD (Bremner et al. 1997). In patients who relapsed, post-RTD PET scans indicated decreases in brain metabolism in dorsolateral prefrontal cortex, thalamus, and orbitofrontal cortex, compared to pre-RTD baseline metabolic measurements. Patients not relapsing with RTD did not show these changes. In addition to post-RTD changes, patients who relapsed may have been different from non-relapsers in baseline metabolic measurements of prefrontal and limbic regions.

Endocrine responses to serotonergic drug challenge also differentiate depressives from healthy controls. Pituitary release of several hormones is triggered by serotonergic activation of hypothalamic hormone-releasing signals. In particular, serotonergic drugs appear to enhance release into plasma of prolactin, growth hormone, and ACTH in healthy volunteers. These measures are consistently decreased in depressed patients in response to general serotonergic challenge with L-TRP or the serotonin releaser, fenfluramine (Cowen 1993). These lowered neuroendocrine responses to serotonergic challenges in depressed patients are thought to reflect pathologically diminished levels of serotonin release in depression. If so, RTD should lower these already abnormally low responses to 5-HT drug challenge. However, if RTD-associated attenuation of 5-HT release induces alterations in the functional sensitivity of 5-HT receptors, neuroendocrine responses to 5-HT challenge will reflect this.

Price and colleagues have demonstrated the latter. In drug-free depressed patients, cortisol responses to intravenous infusions of TRP were significantly greater during RTD than during sham depletion (Price et al. 1998). Similarly, in drug-free depressed patients, i.v. infusion of mCPP (a 5-HT2A/2C receptor agonist) affected serum cortisol greater after RTD than did sham depletion. These enhanced neuroendocrine responses are suggestive of upregulated 5-HT receptor function, presumably a response to lowered 5-HT release (Price et al. 1997).

\section{Does RTD Reverse Other Beneficial Treatments in Mood Disorders?}

In recently remitted patients treated with non-pharmacological interventions hypothesized to have a 5-HTenhancing basis of action, RTD induces full clinical re- 
lapse only rarely (see Table 5). Variable effects on mood have been reported in depressed patients treated with electroconvulsive therapy (Cassidy et al. 1997), in depressed and bipolar patients euthymic following one night of total sleep deprivation (Neumeister et al. 1998a), or in seasonal affective disorder patients treated with bright light therapy (Lam et al. 1996; Neumeister et al. 1997, 1998b; Lenzinger et al. 1999). Cases of RTDinduced full clinical relapse (meeting Delgado et al. (1990) criteria) are rare. In some cases, RTD-induced mood effects occurs outside the time window of plasma TRP depletion, and after plasma TRP has repleted to baseline levels. There have been no RTD investigations in recently remitted patients treated with cognitive behavior therapy or interpersonal psychotherapy alone.

Manic Symptoms. In terms of manic symptoms in patients with bipolar disorder, RTD again elicits mixed responses. Fully remitted patients treated with lithium for a minimum of one year show no significant changes in either depressive mood or manic symptoms (Benkelfat et al. 1995). There are two reports in recently remitted lithium-treated mania. Cappiello et al. (1997) found exacerbated mania in two of seven patients, though Cassidy et al. (1997) reported no change in four patients. Taken together, this suggests that lithium may exerts its beneficial effects on the serotonin system in only a subset of patients.

\section{RTD's Effects on Unaffected Subjects at Risk for Depressive Illness}

Mood Effects in Healthy Volunteers Predisposed to Depression. Genetic, familial, or gender-related vulnerability to depressive disorders in never-depressed subjects has provided intriguing, yet mixed, results (see Table 6). Scores on the depression subscale of the selfrated Profile of Mood States (POMS) were significantly more affected after RTD in males who had a strong family history of depression than in never-depressed males with no family history (Benkelfat et al. 1994). Healthy, non-depressed women have shown RTD-induced worsening in POMS subscales (Ellenbogen et al. 1996). In one report, healthy non-depressed women with a family history of depression were more likely to show subtle mood and gastrointestinal changes than those with no family history (Klaassen et al. 1999b), but another investigation in healthy non-depressed familyhistory-positive women showed no change in mood ratings (Ellenbogen et al. 1999).

\section{RTD, Mood, and Physiologic Variables in Healthy Subjects}

Mood Changes. In healthy subjects, clinically significant RTD-induced changes of mood are rare and gener- ally mild (see Table 7). No study reports the induction of a depressive state measured by HDRS in wellscreened healthy subjects. Mood changes are typically subtle and measurable only using subjective rating scales, and even these have been inconsistently reported. Mood-lowering effects on the depression subscale of the Multiple Affective Adjective Checklist (MAACL) have been reported in healthy young men (Young et al. 1985). However, a lack of significant mood consequences using these and other subjective mood assessments has also been reported by Danjou et al. (1990), Abbott et al. (1992), and Oldman et al. (1994). In addition, healthy subjects who were administered SSRIs for six weeks and then challenged with RTD did not produce any measurable changes in mood (Barr et al. 1997).

Higher Cognitive Function, Neuroendocrine Measures, Immune Responses, and Pain Perception. There are also reports of RTD-induced alterations in attention (Coull et al. 1995), and RTD-induced impairments in performance on certain types of learning and memory (Park et al. 1994; Riedel et al. 1999). A variety of immune responses were not substantially altered by RTD (Ravindran et al. 1999). Pain threshold and pain tolerance were not affected by RTD nor sham challenge, but RTD reduced the analgesic effect of morphine (Abbott et al. 1985), suggesting serotonin's influence on pain pathways.

\section{Are There Non-Serotonergic Explanations for the Effects of RTD?}

The tryptophan-free challenge contains other amino acids, some of which possess neuroactive or neurotransmitter-like properties (such as glycine (Gly), and Gly receptors can also be activated by alanine, serine, and proline). Other amino acids such as tyrosine are precursors for other neurotransmitters (dopamine and norepinephrine). Given that these amino acids are present in the same amounts in TRP-free and TRP-containing preparations, and that sham depletion techniques have measurable effects only rarely, the discrepancy between the effects seen with TRP-free and TRP-containing challenges therefore cannot be accounted for by simply having taken in a huge bolus of amino acids. In support of this, Klaassen et al. (1999a) depleted healthy subjects either of TRP or lysine, using a similar preparation. Unlike RTD, rapid lysine depletion provoked no measurable mood or memory effects. This is taken as evidence that RTD's effects are indeed due to the specific depletion of tryptophan.

If it can be assumed that RTD reduces 5-HT release, other neurotransmitter systems may be affected. In this way, the RTD paradigm does not necessarily indict the 5-HT system as neuropathological, 


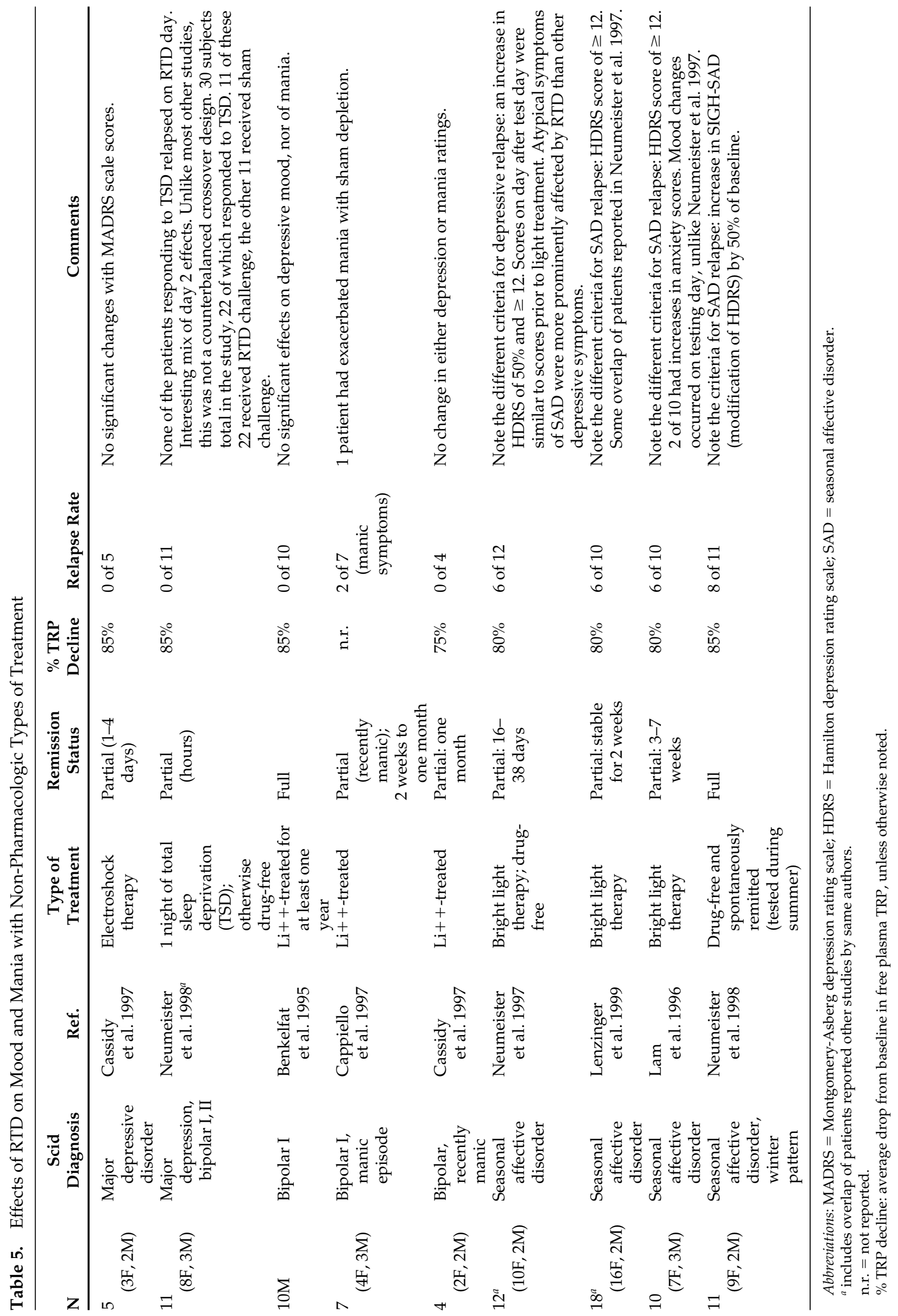


Table 6. Effects of RTD in Unaffected (Non Depressed) Subjects at Risk for Mood Disorders

\begin{tabular}{|c|c|c|c|c|}
\hline Ref. & $\mathbf{N}$ & Mood Measure & $\begin{array}{l}\text { \% TRP } \\
\text { Decline }\end{array}$ & Effects and Comments \\
\hline $\begin{array}{l}\text { Benkelfat } \\
\text { et al. } 1994\end{array}$ & $\begin{array}{l}39 \text { M, with or } \\
\text { without a family } \\
\text { history of } \\
\text { depression }\end{array}$ & $\begin{array}{l}\text { POMS, HDRS, Beck } \\
\text { depression } \\
\text { inventory, VAS. }\end{array}$ & $89 \%$ & $\begin{array}{l}6 \text { of } 20 \text { family history positive subjects showed a 10-pt } \\
\text { change in POMS-depression subscale; none of } 19 \\
\text { family history negative subjects had such a response. } \\
\text { No indication of depressive mood in other measures. }\end{array}$ \\
\hline $\begin{array}{l}\text { Ellenbogen } \\
\text { et al. } 1996\end{array}$ & $\begin{array}{l}20 \mathrm{~F}^{\mathrm{a}} \text {, without } \\
\text { family history of } \\
\text { depression }\end{array}$ & $\begin{array}{l}\text { POMS, VAS: } \\
\text { females screened } \\
\text { to be family } \\
\text { history negative }\end{array}$ & $80 \%$ & $\begin{array}{l}\text { Used an } 86 \mathrm{~g} \text { challenge. Four POMS subscales } \\
\text { (Depresion, Tired, Unsure, Confused) indicated a } \\
\text { lowering of mood. These mood effects were lost on } \\
\text { re-test one month later. }\end{array}$ \\
\hline $\begin{array}{l}\text { Ellenbogen } \\
\text { et al. } 1999\end{array}$ & $\begin{array}{l}14 \mathrm{~F}^{\mathrm{a}} \text {, with family } \\
\text { history of } \\
\text { depression }\end{array}$ & $\begin{array}{l}\text { POMS, VAS: FH + } \\
\text { for major } \\
\text { affective disorder } \\
\text { (three family } \\
\text { members in two } \\
\text { generations) }\end{array}$ & $85 \%$ & $\begin{array}{l}\text { Family history was defined by presence of at least three } \\
\text { affected family members in two generations. Used } \\
\text { an } 86 \mathrm{~g} \text { challenge. Counter to prior report, there were } \\
\text { no significant effects on mood measures. }\end{array}$ \\
\hline $\begin{array}{l}\text { Moreno } \\
\text { et al. } 1999\end{array}$ & $\begin{array}{l}12 \text { drug free } \\
\text { patients with } \\
\text { history of } \\
\text { depression }(8 \mathrm{~F}, \\
4 \mathrm{M})\end{array}$ & HDRS & $85 \%$ & $\begin{array}{l}\text { Two patients with history of depression met relapse } \\
\text { criteria of Delgado et al. (1990). No control subjects } \\
\text { became depressed. }\end{array}$ \\
\hline $\begin{array}{l}\text { Leyton } \\
\quad \text { et al. } 1997\end{array}$ & $\begin{array}{l}14^{a} \text { drug free } \\
\text { patients with } \\
\text { history of } \\
\text { depression }(8 \mathrm{~F}, \\
6 \mathrm{M})\end{array}$ & HDRS & $88 \%$ & $\begin{array}{l}\text { No patients experienced a depressive relapse. In fact, } \\
\text { there were no measurable changes in mood. }\end{array}$ \\
\hline $\begin{array}{l}\text { Smith } \\
\quad \text { et al. } 1997\end{array}$ & $\begin{array}{l}\text { 15F with history of } \\
\text { multiple episode } \\
\text { history of } \\
\text { depression }\end{array}$ & HDRS & $75 \%$ & $\begin{array}{l}\text { Five of } 15 \text { were reported to relapse using different } \\
\text { criteria. Fewer than } 5 \text { (estimate: 2) met Delgado et al. } \\
\text { (1990) criteria for relapse. }\end{array}$ \\
\hline
\end{tabular}

Abbreviations: POMS = profile of mood states; HDRS = Hamilton depression rating scale; VAS = visual analog scale.

a indicates a study including female subjects in which menstrual cycle phase was controlled for.

$\$$ indicates a study including female subjects in which menstrual cycle is addressed but not controlled for.

$\%$ TRP decline: average drop from baseline in free plasma TRP, unless otherwise $n$.

it simply uncovers other systems being modulated, modified, or regulated by 5-HT. As stated previously, the projection sites of 5-HT neurons extend over much of the CNS, and the scope of 5-HT's influence may be vast. Sudden withdrawal of 5-HT's presumed modulatory presence might result in counterregulatory changes in other systems.

It is also unknown what a sudden drop in TRP levels does to enzymatic activity of TRP hydroxylase (TRP-H). There is evidence that dramatic diminution of brain TRP elicits increases in TRP-H activity (Neckers et al. 1977). It is unknown to what extent putative increases in TRP-H activity affect total 5-HT synthesis and release, but a compensatory mechanism such as this could theoretically offset any decrement in 5-HT production.

It is unknown how much of the body's total TRP is used for 5-HT metabolism (Kuhn et al. 1986). It is also possible that depleting TRP via RTD affects the synthesis of other TRP-containing compounds, and not (only) the synthesis of 5-HT. Since TRP is an amino acid and a constituent of many proteins - including various neurohormones and neuropeptides - depleting TRP might affect de novo synthesis of these products. Theoreti- cally, a sudden drop in level of neuroactive substances like these might be responsible for the effects of RTD.

For example, with regard to the REM sleep disinhibiting effects of RTD: the so-called delta-sleep inducing peptide (DSIP) contains TRP at its $\mathrm{N}$-terminus (TRPAla-Gly-Gly-Asp-Ala-Ser-Gly-Glu). DSIP has been postulated as a substance that accumulates in the brain during wakefulness, and is discharged or dissipated during delta non-REM sleep. If this is so, then RTD-induced decline in DSIP production, rather than diminished 5-HT synthesis, might account for the reduced REM latencies associated with RTD. By contrast, other substances that might also have accounted for the RTDinduced REM-hastening effect - such as vasoactive intestinal peptide, which decelerates the non-REM-REM cycle (Murck et al. 1996) - do not contain TRP.

TRP is a constituent of somatostatin, for example. Lowered CSF levels of somatostatin, lowered blood levels of somatostatin-like immunoreactivity, or abnormalities in somatostatin gene expression have been associated with depressive mood in patients (Rubinow et al. 1983; Dinan 1998; Markou et al. 1998) or in animal models of depression (Gomez et al. 1999; 


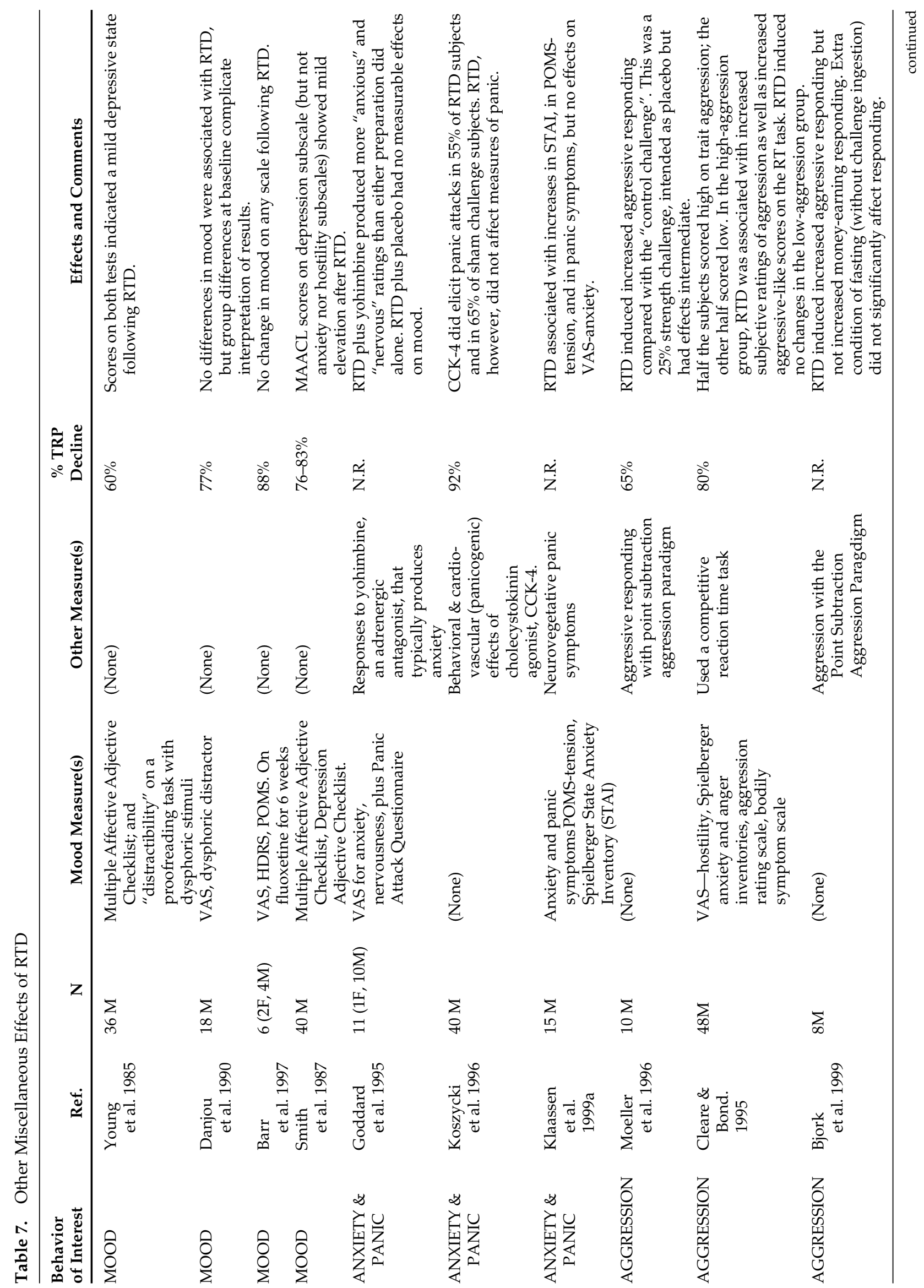




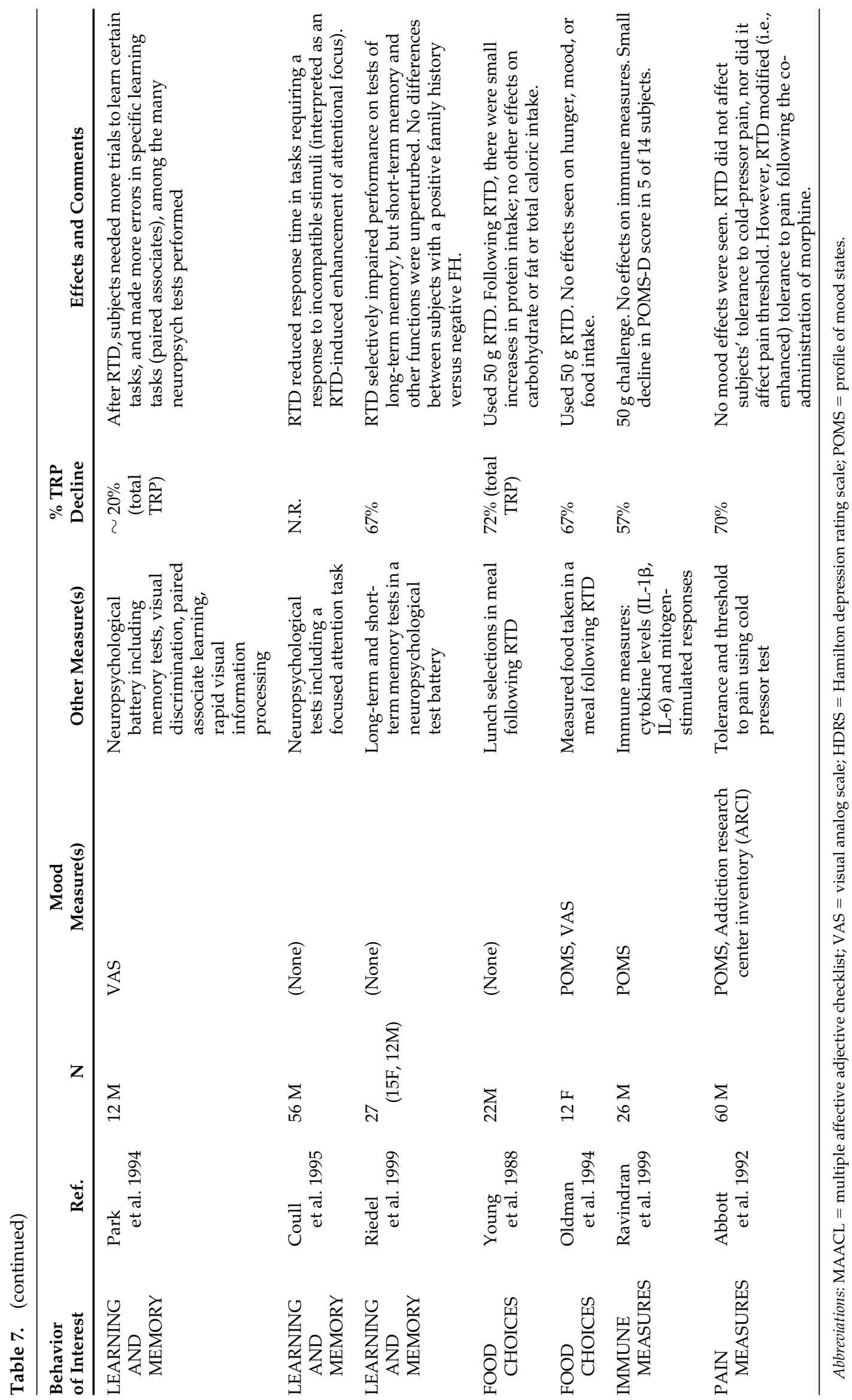


Mathe 1999; Zhang et al. 1999; Holmes et al. 1998; Heuser et al. 1998). Therefore, somatostatin may be a peptide whose synthesis mediates the depressioninducing effects of RTD. Whether sudden changes in somatostatin levels can induce (temporary) depressive symptoms is unknown, but may be worthy of exploration. Other regulatory proteins that may contain TRP - neurotransmitter receptors, ion channels, enzymes involved with neurotransmitter synthesis and degradation - also affect neuronal function. These other possibilities have not been investigated with respect to RTD. The assumption remains that 5-HT is the most parsimonious TRP "metabolite" capable of producing the spectrum of RTD effects.

\section{SUMMARY}

Several issues are important to consider in RTD-induced depressive relapse. Medication status, duration of treatment, degree of remission, plasma TRP levels, gender, gastrointestinal side effects and individual predisposition all may play a role. These hypotheses are testable. More research may be needed regarding the reversal of antidepressant effect in SSRI/MAOI treated patients, and in OCD and panic disorder as well. There is circumstantial evidence supporting the notion of (temporary) decreased serotonin release from neurons following RTD. Effects of RTD on lowering plasma TRP are consistent and robust. The most dramatic symptoms tend to occur in partially remitted depressed patients on serotoninergic pharmacotherapy. However, this has yet to be replicated by independent groups. With regard to other non-mood measures, certain measures presumably under serotonergic control (such as REM sleep regulation) may remain sensitive to RTD after full remission with SSRIs or MAOIs, though mood and other depressive symptoms may not.

RTD has helped to illuminate some of the enormous complexity of serotonin's role in human behavior. Its main advantage has been its comparative lack of longterm ill effects. There has been controversy about the ethical underpinnings of research "challenge" protocols in which patients are hypothesized to experience increased negative symptoms as a result of participation. The same concerns apply to these types of studies. To our knowledge, there have been no serious negative responses of the RTD protocol, such as suicide attempt or hospitalization, although it is possible that such events occur but are reported only to the local institutional review board. According to published reports, when patients are withdrawn from RTD studies it is primarily due to gastrointestinal side effects, i.e., nausea, vomiting, or diarrhea. Perhaps there is a need to develop a central oversight committee or reporting center, such as those used in multi-site clinical trials, to keep track of infrequent but serious side effects in challenge studies like RTD, so that the risk: benefit ratio may be evaluated more critically.

\section{ACKNOWLEDGMENTS}

Research was supported by grants from: the UCSD General Clinical Research Center's Program (Michael Ziegler, M.D., Director, MOI RR00827); National Institutes of Health (MH 57134-01 and MH 18825); UCSD Mental Health Clinical Research Center (MH 30914); and the Stanley Foundation, Swiss National Science Foundation (Grant No. 3200-0512094.97), and the University of Basel.

\section{REFERENCES}

Abbott FV, Etienne P, Franklin KBJ, Morgan MJ, Sewitch MJ, Young SN (1992): Acute tryptophan depletion blocks morphine analgesia in the cold-pressor test in humans. Psychopharmacology 108:60-66

Aberg-Wistedt A, Hasselmark L, Stain-Malmgren R, Aperia B, Kjellman BF, Mathe AA (1998): Serotonergic 'vulnerability' in affective disorder: A study of the tryptophan depletion test and relationships between peripheral and central serotonin indexes in citalopram-responders. Acta Psychiatr Scand 97:374-380

Aronson SC, Black JE, McDougle CJ, Scanley BE, Jatlow P, Kosten TP, Heninger GR, Price LH (1995): Serotonergic mechanisms of cocaine effects in humans. Psychopharmacology 19:179-185

Artigas F, Bel N, Casanovas JM, Romero L (1996): Adaptative changes of the serotonergic system after antidepressant treatments. In Filippini GA (ed), Recent Advances in Tryptophan Research. New York, Plenum Press, pp 51-59

Barr LC, Goodman WK, McDougle CJ, Delgado PL, Heninger GR, Charney DS, Price LH (1994): Tryptophan depletion in patients with obsessive compulsive disorder who respond to serotonin reuptake inhibitors. Arch Gen Psychiatry 51:309-317

Barr LC, Heninger GR, Goodman W, Charney DS, Price LH (1997): Effects of fluoxetine administration on mood response to tryptophan depletion in healthy subjects. Biol Psychiatry 41:949-954

Baumgarten HG, Grozdanovic Z (1994): Neuroanatomy and neurophysiology of central serotonergic systems. J Serotonin Res 1:171-179

Baumgarten HG, Grozdanovic Z (1995): Psychopharmacology of central serotonergic systems. Pharmacopsychiatry 28(Suppl):73-79

Bel N, Artigas F (1996): Reduction of serotonergic function in rat brain by tryptophan depletion: Effects in control and fluvoxamine-treated rats. J Neurochem 67:669-676

Benca RM, Obermeyer WH, Thisted RA, Gillin JC (1992): Sleep and psychiatric disorders: A meta-analysis. Arch Gen Psychiatry 49:651-668

Benkelfat C, Ellenbogen MA, Dean P, Palmour RM, Young SN (1994): Mood-lowering effect of tryptophan deple- 
tion: enhanced susceptibility in young men at risk for major affective disorder. Arch Gen Psychiatry 51:687-697

Benkelfat C, Seletti B, Palmour RM, Hillel J, Ellenbogen M, Young SM (1995): Tryptophan depletion in stable lithium-treated patients with bipolar disorder in remission. Arch Gen Psychiatry 52:154-155

Bhatti T, Gillin JC, Seifritz E, Moore P, Clark C, Golshan S, Stahl S, Rapaport M, Kelsoe J (1998): Effects of a tryptophan-free amino acid drink challenge on normal human sleep EEG and mood. Biol Psychiatry 43:52-59

Biggio G, Fadda F, Fanni P, Tagliamonti A, Gessa GL (1974): Rapid depletion of serum tryptophan, serotonin, and 5hydroxyindoleacetic acid by a tryptophan-free diet. Life Sci 14:1321-1329

Bjork JM, Dougherty DM, Moeller FG, Cherek DR, Swann AC (1999): The effects of tryptophan depletion and loading on laboratory aggression in men: Time course and a food-restricted control. Psychopharmacology 142:24-30

Blier P, de Montigny C (1994): Current advances and trends in the treatment of depression. Trends Pharmacol Sci 15:220-226

Bremner JD, Innis RB, Salomon RM, Staib LH, Ng CK, Miller HL, Bronen RA, Krystal JH, Duncan J, Rich D, Price LH, Malison R, Dey H, Soufer R, Charney DS (1997): Positron emission tomography measurement of cerebral metabolic correlates of tryptophan depletioninduced depressive relapse. Arch Gen Psychiatry 54:364-374

Brown CM, Fletcher PJ, Coscina DV (1998): Acute amino acid loads that deplete brain serotonin fail to alter behavior. Pharmacol Biochem Behav 59:115-121

Cappiello A, Sernyak MJ, Malison RT, McDougle CJ, Heninger GR, Price LH (1997): Effects of acute tryptophan depletion in lithium-remitted manic patients: A pilot study. Biol Psychiatry 42:1076-1078

Carpenter LL, Anderson GM, Pelton GH, Gudin JA, Kirwin PDS, Price LH, Heninger GR, McDougle CJ (1998): Tryptophan depletion during continuous SCF sampling in healthy human subjects. Neuropsychopharmacology 19:26-35

Cassidy F, Murry E, Weiner RD, Carroll BJ (1997): Lack of relapse with tryptophan depletion following successful treatment with ECT. Am J Psychiatry 154:1151-1152

Cleare AJ, Bond AJ (1995): The effect of tryptophan depletion and enhancement on subjective and behavioral aggression in normal male subjects. Psychopharmacology 118:72-81

Coccaro EF, Kavoussi RJ, Cooper TB, Hauger R (1998): Acute tryptophan depletion attenuates the prolactin response to d-fenfluramine challenge in healthy human subjects. Psychopharmacology 138:9-15

Coull JT, Sahakian BJ, Middleton HC, Young AH, Park SB, McShance RH, Cowen PJ, Robbins TW (1995): Differential effects of clonidine, haloperidol, diazepam, and tryptophan depletion on focused attention and attentional search. Psychopharmacology 121:222-230

Cowen PJ (1993): Serotonin receptor subtypes in depression: Evidence from studies in neuroendocrine regulation. Clin Neuropharmacol 16:S6-S18

Cowen PJ, Williamson DJ, McTavish SFB (1996): Effect of valine on 5-HT neurotransmission and mood. In Filippini GA (ed), Recent Advances in Tryptophan Research. New York, Plenum Press, pp 67-71

Curzon G (1979): Relationships between plasma, CSF, and brain tryptophan. J Neural Trans Suppl 15:81-92

Danjou P, Harmon M, Lacamblez L, Warot D, Kecskemeti S, Puech AJ (1990): Psychomotor, subjective, and neuroendocrine effects of acute tryptophan depletion in the healthy volunteer. Psychiatry Psychobiol 5:31-38

Delgado PL, Charney DS, Price LH, Aghajanian GK, Landis H, Heninger GR (1990): Serotonin function and the mechanism of antidepressant action: Reversal of antidepressant-induced remission by rapid depletion of plasma tryptophan. Arch Gen Psychiatry 47:411-418

Delgado PL, Charney DS, Price LH, Landis H, Heninger GR (1989): Neuroendocrine and behavioral effects of dietary tryptophan restriction in healthy subjects. Life Sci 45:2323-2332

Delgado PL, Miller HL, Salomon RM, Licinio J, Heninger GR, Gelenberg AJ, Charney DS (1993): Monoamines and the mechanism of antidepressant action: Effects of catecholamine depletion on mood of patients treated with antidepressants. Psychopharmacol Bull 29:389-393

Delgado PL, Miller HL, Salomon RM, Licinio J, Krystal JH, Moreno FA, Heninger GR, Charney DS (1999): Tryptophan-depletion challenge in depressed patients treated with desipramine or fluoxetine: Implications for the role of serotonin in the mechanism of antidepressant action. Biol Psychiatr 46:212-220

Delgado PL, Price LH, Miller HL, Salomon RM, Aghajanian GK, Heninger GR, Charney DS (1994): Serotonin and the neurobiology of depression: Effects of tryptophan depletion in drug-free depressed patients. Arch Gen Psychiatry 51:865-874

Delgado PL, Price LH, Miller HL, Salomon RM, Licinio J, Krystal JH, Heninger GR, Charney DS (1991): Rapid serotonin depletion as a provocative challenge test for patients with major depression: Relevance to antidepressant action and the neurobiology of depression. Psychopharmacol Bull 27:321-330

Dinan TG (1998): Psychoneuroendocrinology of depression: Growth hormone. Psychiatr Clin N Am 21:325-339

Ellenbogen MA, Young SN, Dean P, Palmour RM, Benkelfat C (1996): Mood response to acute tryptophan depletion in healthy volunteers: Sex differences and temporal stability. Neuropsychopharmacology 15:465-474

Ellenbogen MA, Young SN, Dean P, Palmour RM, Benkelfat C (1999): Acute tryptophan depletion in healthy young women with a family history of major affective disorder. Psychol Med 29:35-46

Engelman K, Lovenberg W, Sjoerdsma A (1967): Inhibition of serotonin synthesis by para-chlorophenylalanine in patients with the carcinoid syndrome. New Engl J Med 277:1103-1108

Fernstrom JD (1979): Diet-induced changes in plasma amino acid pattern: Effects on the brain uptake of large neutral amino acids, and on brain serotonin synthesis. J Neural Transm Suppl 15:55-67

Fernstrom JD, Wurtman RJ (1974): Nutrition and the brain. Sci Am 84-91 
Fernstrom JD, Wurtman RJ, Hammarstrom-Wiklund B, Rand WM, Munro HN, Davidson CS (1979): Diurnal variations in plasma concentrations of tryptophan, tyrosine, and other neutral amino acids: Effect of dietary protein intake. Am J Clin Nutr 32:1912-1922

Fornal CA, Litto WJ, Metzler CW, Marrosu F, Tada K, Jacobs BL (1994): Single-unit responses of serotonergic dorsal raphe neurons to $5-\mathrm{HT}_{1 \mathrm{~A}}$ agonist and antagonist drug administration in behaving cats. J Pharmacol Exp Ther 270:1345-1358

Gartside SE, Cowen PJ, Sharp T (1992a): Effect of amino acid loads on hippocampal 5-HT release in vivo evoked by electrical stimulation of the dorsal raphe nucleus and d-fenfluramine administration. Br J Pharmacol 107:448P

Gartside SE, Cowen PJ, Sharp T (1992b): Evidence that the large neutral amino acid L-valine decreases electricallyevoked release of 5-HT in the rat hippocampus in vivo. Psychopharmacology 109:251-253

Gartside SE, Cowen PJ, Sharp T (1992c): Effect of 5-hydroxyL-tryptophan on the release of 5-HT in the rat hypothalamus in vivo as measured by microdialysis. Neuropharmacology 31:9-14

Gessa GL, Biggio G, Fadda F, Corsini GV, Tagliamonte A (1974): Effect of oral administration of tryptophan-free amino acid mixtures on serum tryptophan, brain tryptophan, and serotonin metabolism. J Neurochem 22:869-870

Gillin JC, Rapaport M, Erman MK, Winokur A, Albala BJ (1997): A comparison of nefazodone and fluoxetine on mood and on objective, subjective, and clinician-rated measures of sleep in depressed patients: A double-blind 8-week clinical trial. J Clin Psychiatry 58:185-192

Goddard AW, Charney DS, Germine M, Woods SW, Heninger GR, Krystal JH, Goodman WK, Price LH (1995): Effects of tryptophan depletion on responses to yohimbine in healthy human subjects. Biol Psychiatry 38:74-85

Gomez F, Grauges P, Lopez-Calderon A, Armario A (1999): Abnormalities of hypothalamic-pituitary-adrenal and hypothalamic-somatotrophic axes in Fawn-Hooded rats. Eur J Endocrinol 141:290-296

Heuser I, Bissette G, Dettling M, Schwiger U, Gotthardt U, Schmider J, Lammers CH, Nemeroff CB, Holsboer F (1998): Cerebrospinal fluid concentrations of corticotropin-releasing hormone, vasopressin, and somatostatin in depressed patients and healthy controls: Response to amitryptiline treatment. Depress Anxiety 8:71-79

Heninger GR, Delgado PL, Charney DS (1996): The revised monoamine theory of depression: A modulatory role for monoamines, based on new findings from monoamine depletion experiments in humans. Pharmacopsychiatry 29:2-11

Holmes PV, Davis RC, Masini CV, Primeaux SD (1998): Effects of olfactory bulbectomy on neuropeptide gene expression in the rat olfactory/limbic system. Neuroscience 86:587-596

Jacobs BL, Wilkinson LO, Fornal CA (1990): The role of brain serotonin: A neurophysiologic perspective. Neuropsychopharmacology 3:473-479

Jouvet M, Bobillier P, Pujol JF, Renault J (1967): Permanent insomnia and diminution of cerebral serotonin due to lesion of the raphe system in cats. J Physiol (Paris) 59 (1 Suppl):248

Kent JM, Coplan JD, Martinez J, Karmally W, Papp LA, Gorman JM (1996): Ventilatory effects of tryptophan depletion in panic disorder: A preliminary report. Psychiatr Res 64:83-90

Klaassen T, Klumperbeek J, Deutz NEP, van Praag HM, Griez E (1998): Effects of tryptophan depletion on anxiety and on panic provoked by carbon dioxide challenge. Psychiatr Res 77:167-174

Klaassen T, Riedel WJ, Deutz NEP, van Someren A, van Praag HM (1999a): Specificity of the tryptophan depletion method. Psychopharmacology 141:279-286

Klaassen T, Riedel WJ, van Someren A, Deutz NEP, Honig A, van Praag HM (1999b): Mood effects of 24-hour tryptophan depletion in healthy first-degree relatives of patients with affective disorders. Biol Psychiatry 46:489-497

Koella WP, Feldstein A, Czicman JS (1968): The effect of para-chlorophenylalanine on the sleep of cats. Electroencephalogr Clin Neurophysiol 25:481-490

Koszycki D, Zacharko RM, Le Melledo J-M, Young SN, Bradwejn J (1996): Effect of acute tryptophan depletion on behavioral, cardiovascular, and hormonal sensitivity to cholecystokinin-tetrapeptide challenge in healthy volunteers. Biol Psychiatry 40:648-655

Kuhn DM, Wolf WA, Youdim MBH (1986): Serotonin neurochemistry revisited: A new look at some old axioms. Neurochem Int 8:141-154

Lam RW, Zis AP, Grewal A, Delgado PL, Charney DS, Krystal JH (1996): Effects of rapid tryptophan depletion in patients with seasonal affective disorder in remission after light therapy. Arch Gen Psychiatry 53:41-44

Landolt HP, Posthuma D, Raimo EB, Schlosser A, Gillin JC (1999): Almost complete absence of REM sleep in a depressed patient during six months on phenelzine. Sleep Res online 2 (Suppl 1): 540

Landolt HP, Schnierow BJ, Kelsoe JR, Rappaport MH, Gillin JC (2000): Phenelzine-induced supression of REM sleep can be reversed by rapid tryptophan depletion. Sleep 23(Suppl 2):A34

Lanoir J, Ternaux JP, Pons C, Lagarde JM (1981): Long-term effects of a tryptophan-free diet on serotonin metabolism and sleep-waking balance in rats. Exp Brain Res 41:346-357

LeMarquand DG, Pihl RO, Young SN, Tremblay RE, Seguin JR, Palmour RM, Benkelfat C (1998): Tryptophan depletion, executive functions, and disinhibition in aggressive, adolescent males. Neuropsychopharmacology 19:333-341

Lenzinger E, Neumeister A, Praschak-Reider N, Fuchs K, Gerhard E, Willeit M, Sieghard W, Kasper SF, Hornik K, Aschauer HN (1999): Behavioral effects of tryptophan depletion in seasonal affective disorder associated with the serotonin transporter gene? Psychiatr Res 85:241246

Leyton M, Young SN, Blier P, Ellenbogen MA, Palmour RM, Ghadirian A-M, Benkelfat C (1997): The effect of tryptophan depletion on mood in medication-free, former patients with major affective disorder. Neuropsychopharmacology 16:294-297 
Lin RC, Costa E, Neff NH, Wang CT, Ngai SH (1969): In vivo measurement of 5-hydroxytryptamine turnover rate in the rat brain from the conversion of $\mathrm{C}_{14}$-tryptophan to $\mathrm{C}_{14}$-5-hydroxytryptamine. J Pharmacol Exp Ther 170:232-238

Markou A, Kosten TR, Koob GF (1998): Neurobiological similarities in depression and drug dependence: A selfmedication hypothesis. Neuropsychopharmacology 18:135-74

Mathe AA (1999): Neuropeptides and electroconvulsive treatment. J ECT 15:60-75

McDougle CJ, Naylor ST, Cohen DJ, Aghajanian GK, Heninger GR, Price LH (1996): Effects of tryptophan depletion in drug-free adults with autistic disorder. Arch Gen Psychiatry 53:993-1000

McMenamy RH (1965): Binding of indole analogues to human serum albumin. Effects of fatty acids. J Biol Chem 240:4235-4243

Menkes DB, Coates DC, Fawcett JP (1994): Acute tryptophan depletion aggravates premenstrual syndrome. J Aff Dis 32:37-44

Miller HL, Delgado PL, Salomon RM, Heninger GR, Charney DS (1996): Effects of alpha-methyl-para-tyrosine (AMPT) in drug-free depressed patients. Neuropsychopharmacology 14:151-157

Moeller FG, Dougherty DM, Swann AC, Collins D, Davis CM, Cherek DR (1996): Tryptophan depletion and aggressive responding in healthy males. Psychopharmacology 126:97-103

Moja EA, Cipolla P, Castoldi D, Tofanetti O (1989): Dose response decrease in plasma tryptophan and in brain tryptophan and serotonin after tryptophan-free amino acid mixtures in rats. Life Sci 44:971-976

Moja EA, Mendelson WB, Stoff DM, Gillin JC, Wyatt RJ (1979): Reduction of REM sleep by a tryptophan-free amino acid diet. Life Sci 24:1467-1470

Moja EA, Restani P, Corsini E, Stacchezzini MC, Assereto R, Galli CL (1991): Cyclohexaminde blocks the fall of plasma and tissue tryptophan levels after tryptophanfree amino acid mixtures. Life Sci 49:1121-1128

Moja EA, Stoff DM, Gessa GL, Castoldi D, Assereto R, Tofanetti O (1988): Decreases in plasma tryptophan after tryptophan-free amino acid mixtures in man. Life Sci 42:1551-1556

Moore P, Gillin JC, Bhatti T, DeModena A, Seifritz E, Clark C, Stahl S, Rapaport M, Kelsoe J (1998): Rapid tryptophan depletion, sleep electroencephalogram, and mood in men with remitted depression on serotonin reuptake inhibitors. Arch Gen Psychiatry 55:534-539

Moreno FA, Gelenberg AJ, Heninger GR, Potter RL, McKnight KM, Allen J, Phillips AP, Delgado PL (1999): Tryptophan depletion and depressive vulnerability. Biol Psychiatry 46:498-505

Murck H, Guldner J, Colla-Müller M, Frieboes RM, Schier T, Wiedemann K, Holsboer F, Steiger A (1996): VIP decelerates non-REM-REM cycles and modulates hormone secretion during sleep in men. Am J Physiol 271 (4 Pt 2):R905-11

Neckers LM, Biggio G, Moja E, Meek JL (1977): Modulation of brain tryptophan hydroxylase activity by brain tryptophan content. J Pharmacol Exp Ther 201:110-116
Neumeister A, Praschak-Rieder N, Heáelmann B, Rao M-L, Gluck J, Kasper S (1997): Effects of tryptophan depletion on drug-free patients with seasonal affective disorder during a stable response to bright light therapy. Arch Gen Psychiatry 54:133-138

Neumeister A, Praschak-Rieder N, Heáelmann B, Vitouch O, Rauh M, Barocka A, Tauscher J, Kasper S (1998a): Effects of tryptophan depletion in drug-free depressed patients who responded to total sleep deprivation. Arch Gen Psychiatry 55:167-172

Neumeister A, Turner EH, Matthews JR, Postolache TT, Barnett RL, Rauh M, Vetticad RG, Kasper S, Rosenthal NE (1998b): Effects of tryptophan depletion versus catecholamine depletion in patients with seasonal affective disorder in remission with light therapy. Arch Gen Psychiatry 55:524-530

Nishizawa S, Benkelfat C, Young SN, Leyton M, Mzengeza S, de Montigny C, Blier P, Diksic M (1997): Differences between males and females in rates of serotonin synthesis in human brain. Proc Natl Acad Sci U S A 94:53085313

Oldendorf WH, Szabo J (1976): Amino acid assignment to one of three blood-brain barrier amino acid carriers. Am J Physiol 230:94-98

Oldman A, Walsh A, Salkovskis P, Fairburn CG, Cowen PJ (1995): Biochemical and behavioral effects of acute tryptophan depletion in abstinent bulimic subjects: A pilot study. Psychol Med 25:995-1001

Oldman AD, Walsh AES, Salkovskis P, Laver DA, Cowen PJ (1994): Effect of acute tryptophan depletion on mood and appetite in healthy female volunteers. J Psychopharmacol 8:8-13

Park SB, Coull JT, McShane RH, Young AH, Sahakian BJ, Robbins TW, Cowen PJ (1994): Tryptophan depletion in normal volunteers produces selective impairments in learning and memory. Neuropharmacology 33:575-588

Perez-Cruet J, Chase TN, Murphy DL (1974): Dietary regulation of brain tryptophan metabolism by plasma ratio of free tryptophan and neutral amino acids in humans. Nature 248:693-695

Portas CM, McCarley RW (1994): Behavioral state-related changes of extracellular serotonin concentration in the dorsal raphe nucleus: A microdialysis study of the freely moving rat. Brain Res 648:306-312

Portas CM, Thakkar M, Rainnie D, McCarley RW (1996): Microdialysis perfusion of 8-hydroxy-2-(Di-n-propylamino)tetralin (8-OH-DPAT) in the dorsal raphe nucleus decreases serotonin release and increases rapid eye movement sleep in the freely moving cat. J Neurosci 16:2820-2828

Price LH, Malison RT, McDougle CJ, McCance-Katz EF, Owen KR, Heninger GR (1997): Neurobiology of tryptophan depletion in depression: Effects of m-Chlorophenylpiperazine. Neuropsychopharmacology 17:3 42-350

Price LH, Malison RT, McDougle CJ, Pelton GH, Heninger GR (1998): The neurobiology of tryptophan depletion in depression: Effects of intravenous tryptophan infusion. Biol Psychiatry 43:339-347

Rasmussen AM, Anderson GR, Lynch KA, McSwiggan-Hardin M, Scahill LD, Mazure CM, Goodman WK, Price 
LH, Cohen DJ, Leckman JF (1997): A preliminary study of tryptophan depletion on tics, obsessive-compulsive symptoms, and mood in Tourette's syndrome. Biol Psychiatry 41:117-121

Ravindran AV, Griffiths J, Merali Z, Knott VJ, Anisman H (1999): Influence of acute tryptophan depletion on mood and immune measures in healthy males. Psychoneuroendocrinology 24:99-113

Riedel WJ, Klaassen T, Deutz NEP, van Someren A, van Praag HM (1999): Tryptophan depletion in normal volunteers produces selective impairment in memory consolidation. Psychopharmacology 141:362-369

Rubinow DR, Gold PW, Post RM, Ballenger JC, Cowdry R, Bollinger J, Reichlin S (1983): CSF somatostatin in affective illness. Arch Gen Psychiatry 40:409-412

Salomon RM, Mazure CM, Delgado PL, Mendia P, Charney DS (1994): Serotonin function in aggression: The effect of acute plasma tryptophan depletion in aggressive patients. Biol Psychiatry 35:570-572

Satel SL, Krystal JH, Delgado PL, Kosten TR, Charney DS (1995): Tryptophan depletion and attenuation of cueinduced craving for cocaine. Am J Psychiatry 152:778-783

Schaechter JD, Wurtman RJ (1990): Serotonin release varies with brain tryptophan levels. Brain Res 532:203-210

Sharma RP, Shapiro LE, Kamath SK, Soll EA, Watanabe MD, Davis JM (1997): Acute dietary tryptophan depletion: Effect on schizophrenic positive and negative symptoms. Neuropsychobiology 35:5-10

Sharp T, Bramwell SR, Grahame-Smith DG (1992): Effect of acute administration of L-tryptophan on the release of 5-HT in rat hippocampus in relation to serotoninergic neuronal activity: An in vivo microdialysis study. Life Sci 50:1215-1223

Shopsin B, Friedman E, Gershon S (1976): Parachlorophenylalanine reversal of tranylcypromine effects in depressed patients. Arch Gen Psychiatry 33:811-819

Smeraldi E, Diaferia G, Erzegovesi S, Lucca A, Bellodi L, Moja EA (1996): Tryptophan depletion in obsessivecompulsive patients. Biol Psychiatry 40:398-402

Smith KA, Fairburn CG, Cowen PJ (1997): Relapse of depression after rapid depletion of tryptophan. Lancet 349:915-919

Smith KA, Fairburn CG, Cowen PJ (1999): Symptomatic relapse in bulimia nervosa following acute tryptophan depletion. Arch Gen Psychiatry 56:171-176

Tagliamonte A, Biggio G, Vargiu L, Gessa GL (1973): Free tryptophan in serum controls brain tryptophan level and serotonin synthesis. Life Sci 12:277-287

Tork I (1990): Anatomy of the serotonergic system. Ann N Y Acad Sci 600:9-35
Trulson ME (1985): Dietary tryptophan does not alter the function of brain serotonin neurons. Life Sci 37:10671072

Voderholzer U, Hornyak M, Thiel B, Huwig-Poppe C, Kiemen A, König A, Backhaus J, Riemann D, Berger M, Hohagen F (1998): Impact of experimentally induced serotonin deficiency by tryptophan depletion on sleep EEG in healthy subjects. Neuropsychopharmacology 18:112-124

Weltzin TE, Fernstrom JD, McConaha C, Kaye WH (1994): Acute tryptophan depletion in bulimia: Effects on large neutral amino acids. Biol Psychiatry 35:388-397

Weltzin TE, Fernstrom MH, Fernstrom JD, Neuberger SK, Kaye WH (1995): Acute tryptophan depletion and increased food intake and irritability in bulimia nervosa. Am J Psychiatry 152:1668-1671

Williams WA, Shoaf SE, Hommer D, Rawlings R, Linnoila M (1999): Effects of acute tryptophan depletion on plasma and cerebrospinal fluid and 5-hydroxyindoleacetic acid in normal volunteers. J Neurochem 72:1641-1647

Wurtman RJ, Pardridge WM (1979): Summary: Circulating tryptophan, brain tryptophan, and psychiatric disease. J Neural Transm Suppl 15:227-236

Wurtman RJ, Rose CM, Chou C, Larin FF (1968): Daily rhythms in the concentrations of various amino acids in human plasma. N Engl J Med 279:171-175

Wyatt RJ, Kupfer DJ, Scott J, Robinson DS, Snyder F (1969): Longitudinal studies of the effect of monoamine oxidase inhibitors on sleep in man. Psychopharmacologia 15:236-244

Young SN, Ervin FR, Pihl RO, Finn P (1989): Biochemical aspects of tryptophan depletion in primates. Psychopharmacology 98:508-511

Young SN, Smith SE, Pihl RO, Ervin FR (1985): Tryptophan depletion causes a rapid lowering of mood in normal males. Psychopharmacology 87:173-177

Young SN, Tourjman SV, Teff KL, Pihl RO, Anderson GH (1988): The effect of lowering plasma tryptophan on food selection in normal males. Pharm Biochem Behav 31:149-152

Zhang K, Hamanaka K, Kitayama I, Soya H, Yoshizato H, Nakase S, Uesugi Y, Inui K, Nomura J, Okazaki Y (1999): Decreased expression of the mRNA for somatostatin in the periventricular nucleus of depressionmodel rats. Life Sci 65:PL87-PL94

Zimmerman RC, McDougal CJ, Schumacher M, Olcese J, Mason JW, Heninger GR, Price LH (1993): Effects of acute tryptophan depletion on nocturnal melatonin secretion in humans. J Clin Endocrinol Metab 76:11601164 